In cooperation with the San Antonio Water System

\title{
Simulation of Streamflow and Estimation of Streamflow Constituent Loads in the San Antonio River Watershed, Bexar County, Texas, 1997-2001
}

Water-Resources Investigations Report 03-4030

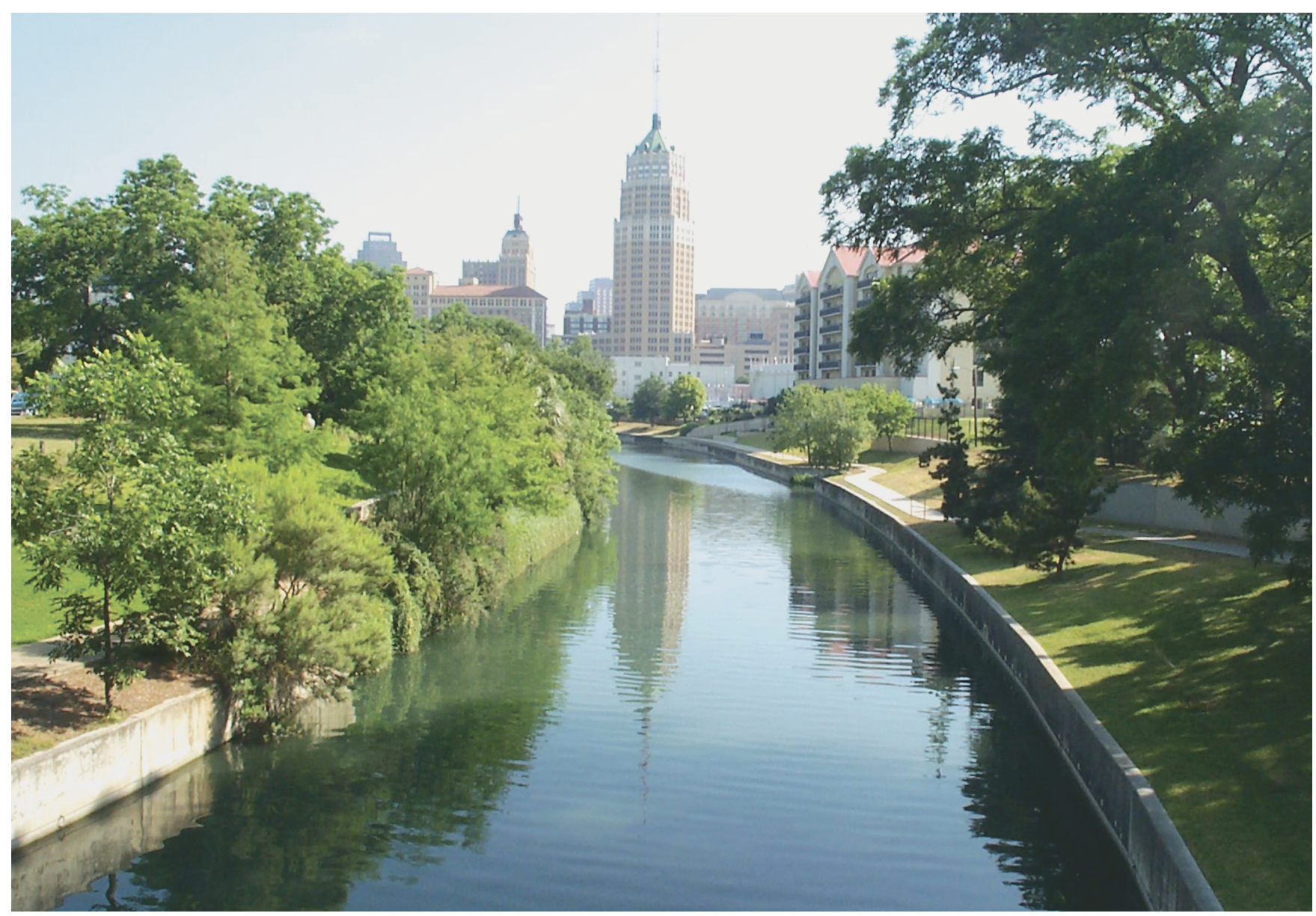

U.S. Department of the Interior

U.S. Geological Survey 


\section{Cover:}

San Antonio River looking upstream toward downtown San Antonio. 
U.S. Department of the Interior

U.S. Geological Survey

\section{Simulation of Streamflow and Estimation of Streamflow Constituent Loads in the San Antonio River Watershed, Bexar County, Texas, 1997-2001}

By Darwin J. Ockerman and Kenna C. McNamara

U.S. GEOLOGICAL SURVEY

Water-Resources Investigations Report 03-4030

In cooperation with the San Antonio Water System

Austin, Texas

2003 


\section{U.S. DEPARTMENT OF THE INTERIOR}

Gale A. Norton, Secretary

\section{U.S. GEOLOGICAL SURVEY}

Charles G. Groat, Director

Any use of trade, product, or firm names is for descriptive purposes only and does not imply endorsement by the U.S. Government.

For additional information write to

\section{District Chief}

U.S. Geological Survey

8027 Exchange Dr.

Austin, TX 78754-4733

E-mail: dc_tx@usgs.gov

Copies of this report can be purchased from

U.S. Geological Survey

Information Services

Box 25286

Denver, CO 80225-0286

E-mail: infoservices@usgs.gov 


\section{CONTENTS}

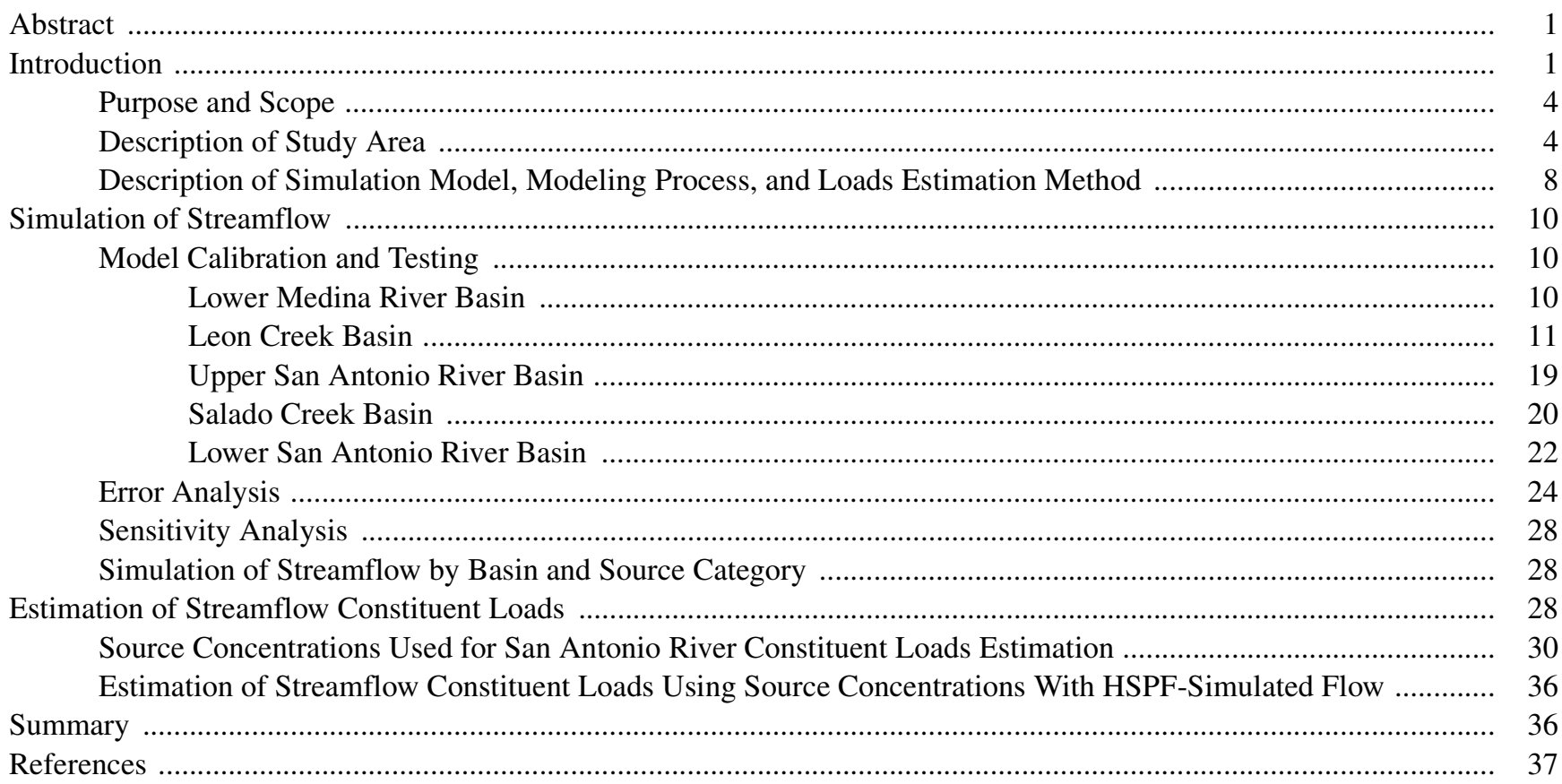

\section{FIGURES}

1-4. Maps showing:

1. San Antonio River watershed, Bexar County, Texas .........................................................................

2. Data-collection sites used for Hydrological Simulation Program-FORTRAN model calibration, testing, simulations, and estimation of streamflow water-quality constituent loads ................................ 3

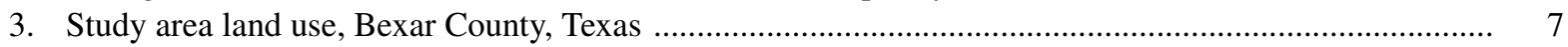

4. Lower Medina River Basin stream and reservoir (RCHRES) segments .............................................. 11

5. Graphs showing measured and simulated 7-day mean streamflow at Medina River at San Antonio, Texas

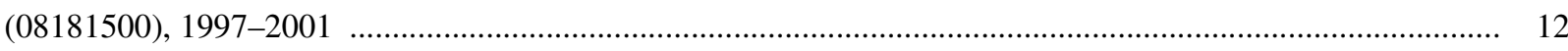

6. Map showing Leon Creek Basin stream and reservoir (RCHRES) segments ................................................ 20

7. Graphs showing measured and simulated 7-day mean streamflow at Leon Creek at IH-35 at San Antonio, Texas (08181480), 1997-2001 ...................................................................................................... 21

8. Map showing upper San Antonio River Basin stream and reservoir (RCHRES) segments ................................ 22

9. Graphs showing measured and simulated 7-day mean streamflow at San Antonio River at Loop 410 at San Antonio, Texas (08178565), 1997-2001 ………....................................................................... 23

10. Map showing Salado Creek Basin stream and reservoir (RCHRES) segments ............................................. 24

11. Graphs showing measured and simulated 7-day mean streamflow at Salado Creek at Loop 13 at San

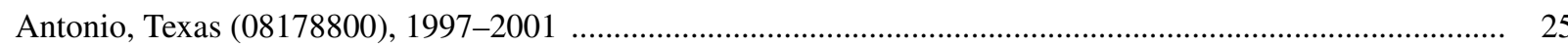

12. Map showing lower San Antonio River Basin stream and reservoir (RCHRES) segments ............................. 26

13. Graphs showing measured and simulated 7-day mean streamflow at San Antonio River near Elmendorf, Texas (08181800), 1997-2001

14. Pie diagram showing contribution to streamflow, in percent, at San Antonio River at Elmendorf, Texas (08181800), 1997-2001

15. Pie diagram showing sources of simulated streamflow, in percent, at San Antonio River near Elmendorf, Texas (08181800), 1997-2001 
16. Graphs showing comparison of streamflow loads estimated from Hydrological Simulation ProgramFORTRAN-simulated flow and source concentrations with loads computed from actual samples at San Antonio River near Elmendorf, Texas (08181800), 1997-2001

17. Pie diagrams showing sources of selected streamflow constituent loads, in percent, San Antonio River near Elmendorf, Texas (08181800), 1997-2001

\section{TABLES}

1. Selected characteristics of basins in the San Antonio River watershed, Bexar County, Texas

2. Data-collection sites used for Hydrological Simulation Program-FORTRAN model calibration, testing, and simulations and estimation of water-quality constituent loads

. Major recycled wastewater discharges, Bexar County, Texas

4. Basin-related model parameters for the Hydrological Simulation Program-FORTRAN _................................ 8

5. Process-related model parameters for the Hydrological Simulation Program_FORTRAN _............................. 9

6. Pervious and impervious land segment areas for basins in the San Antonio River watershed, Bexar

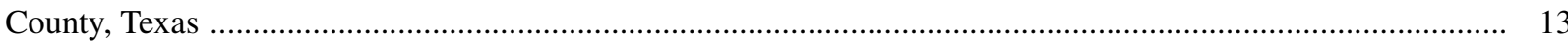

7. Selected annual PERLND and IMPLND process-related parameters for flow, San Antonio River watershed models, Bexar County, Texas

Annual measured and simulated streamflow for basins in the San Antonio River watershed, Bexar

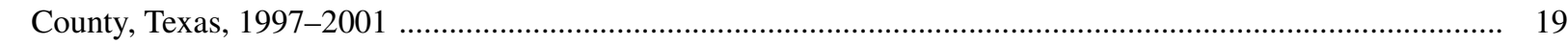

9. Sensitivity of selected annual process-related parameters, Salado Creek Basin, 1997-2001 ........................... 28

10. Sources of simulated streamflow at San Antonio River near Elmendorf, Texas (08181800), 1997-2001 ......... 30

11. Water-quality concentrations used for estimation of streamflow constituent loads ........................................ 31

12. Estimates of selected annual streamflow constituent loads, by source, San Antonio River watershed, Bexar County, Texas, 1997-2000

13. Sources of selected streamflow constituent loads, San Antonio River near Elmendorf, Texas (08181800), 1997-2001 


\title{
Simulation of Streamflow and Estimation of Streamflow Constituent Loads in the San Antonio River Watershed, Bexar County, Texas, 1997-2001
}

\author{
By Darwin J. Ockerman and Kenna C. McNamara
}

\begin{abstract}
The U.S. Geological Survey developed watershed models (Hydrological Simulation Program-FORTRAN) to simulate streamflow and estimate streamflow constituent loads from five basins that compose the San Antonio River watershed in Bexar County, Texas. Rainfall and streamflow data collected during 1997-2001 were used to calibrate and test the model. The model was configured so that runoff from various land uses and discharges from other sources (such as wastewater recycling facilities) could be accounted for to indicate sources of streamflow. Simulated streamflow volumes were used with land-use-specific, water-quality data to compute streamflow loads of selected constituents from the various streamflow sources.
\end{abstract}

Model simulations for 1997-2001 indicate that inflow from the upper Medina River (originating outside Bexar County) represents about 22 percent of total streamflow. Recycled wastewater discharges account for about 20 percent and base flow (ground-water inflow to streams) about 18 percent. Storm runoff from various land uses represents about 33 percent.

Estimates of sources of streamflow constituent loads indicate recycled wastewater as the largest source of dissolved solids and nitrate plus nitrite nitrogen (about 38 and 66 percent, respectively, of the total loads) during 1997-2001. Stormwater runoff from urban land produced about 49 percent of the 1997-2001 total suspended solids load. Stormwater runoff from residential and commercial land (about 23 percent of the land area) produced about
70 percent of the total lead streamflow load during 1997-2001.

\section{INTRODUCTION}

The San Antonio River watershed drains most of the San Antonio, Tex., metropolitan area in Bexar County and comprises five basins-lower Medina River, Leon Creek, upper San Antonio River, Salado Creek, and lower San Antonio River (fig. 1). The lower San Antonio River is the receiving water body for the other basins. Together, the drainage area of these streams is about 934 square miles $\left(\mathrm{mi}^{2}\right)$ (table 1$)$.

Since August 1992 the U.S. Geological Survey (USGS), in cooperation with the San Antonio Water System (SAWS), has operated a stormwater monitoring network consisting of seven stations located in the San Antonio area (fig. 2, sites 13-19). This network is part of the National Pollutant Discharge Elimination System (NPDES) program designed to monitor stormwater quality of small (less than $2 \mathrm{mi}^{2}$ ) urban watersheds (U.S. Environmental Protection Agency, 2002). Each of the monitored watersheds consists of a single,

Table 1. Selected characteristics of basins in the San Antonio River watershed, Bexar County, Texas

\begin{tabular}{lcc}
\hline \multicolumn{1}{c}{ Basin } & $\begin{array}{c}\text { Drainage } \\
\text { area } \\
\text { (square } \\
\text { miles) }\end{array}$ & $\begin{array}{c}\text { Edwards aquifer } \\
\text { catchment area } \\
\text { and outcrop } \\
\text { (square miles) }\end{array}$ \\
\hline Lower Medina River & 306 & 0 \\
Leon Creek & 237 & 114 \\
Upper San Antonio River & 125 & 4 \\
Salado Creek & 223 & 106 \\
Lower San Antonio River & 43 & 0 \\
$\quad$ Total & 934 & 224 \\
\hline
\end{tabular}




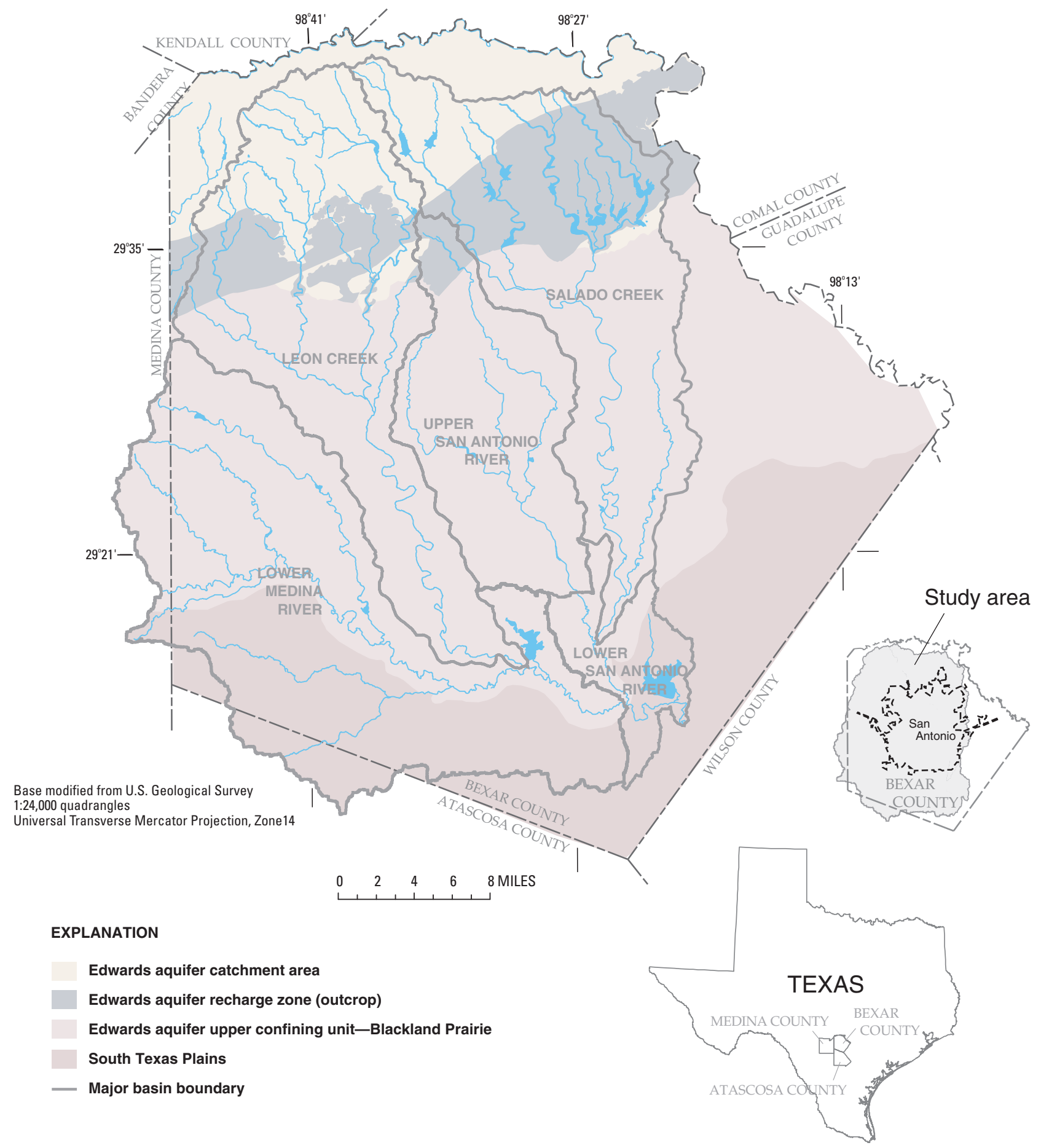

Figure 1. San Antonio River watershed, Bexar County, Texas.

predominant land-use type such as residential, commercial, or industrial. In addition, since May 1996 the USGS, in cooperation with SAWS, has operated a network of seven gages and sampling stations (fig. 2, sites
$5-9,11-12)$ in the Edwards aquifer recharge zone in Bexar County to monitor runoff quality from specific land-use watersheds on the recharge zone (Ockerman and others, 1999). (The Edwards aquifer recharge zone 


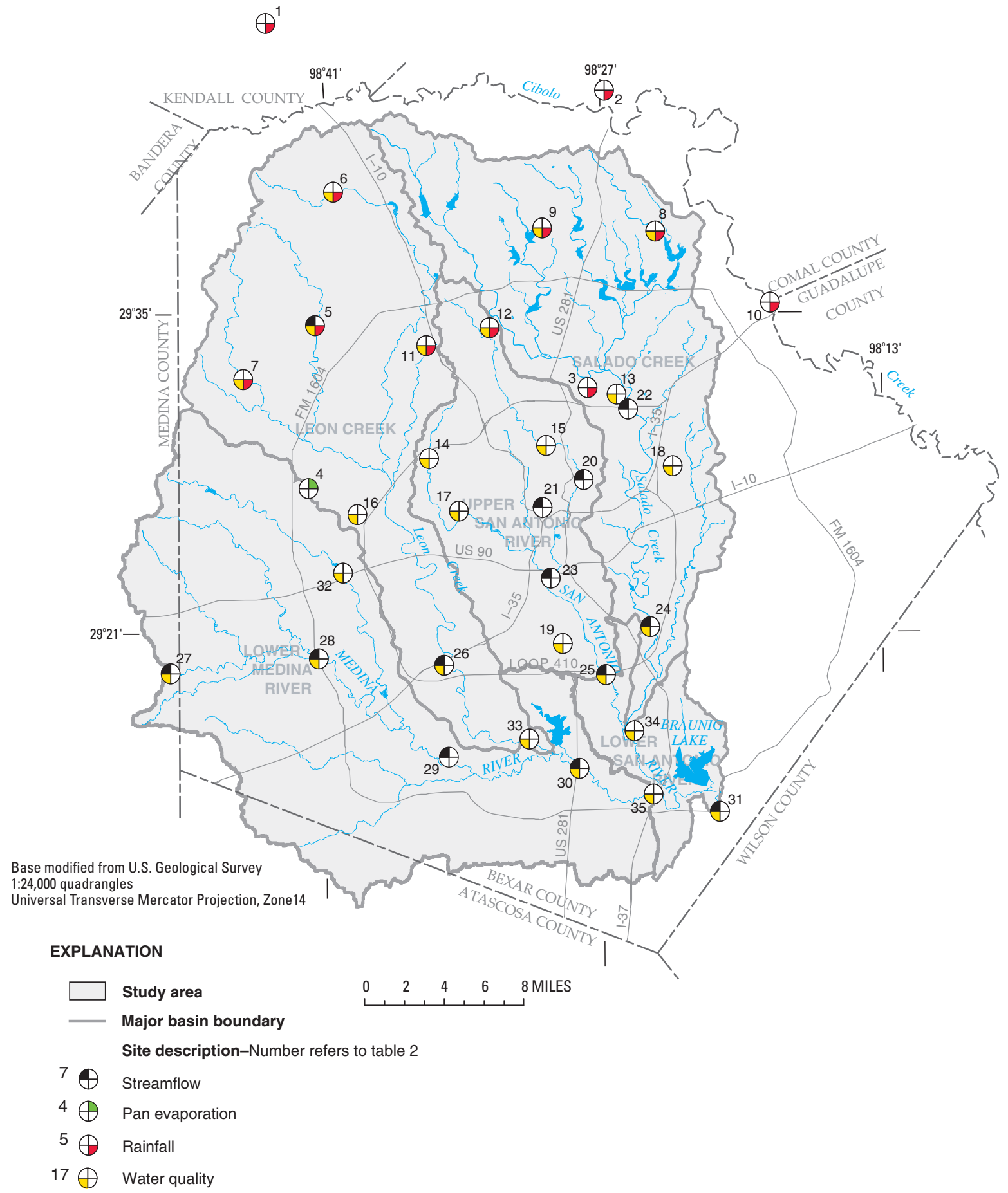

Figure 2. Data-collection sites used for Hydrological Simulation Program—FORTRAN model calibration, testing, simulations, and estimation of streamflow water-quality constituent loads.

is approximately coincident with the Edwards aquifer outcrop and is hereinafter referred to as the Edwards aquifer outcrop.)
In another USGS and SAWS cooperative project, water quality was monitored at five USGS gaging stations (fig. 2, sites 24-26, 30-31) located near the outlets 
of the basins that compose the San Antonio River watershed in Bexar County. The objective of this collection of water-quality data was to characterize baseline waterquality conditions of urban streams and to assess the effects of stormwater runoff on the quality of receiving streams (R.N. Slattery, U.S. Geological Survey, written commun., 2002). In this study, water-quality samples of base flow and stormflow were collected during 199298. Since 1998, water-quality sampling has continued at the USGS streamflow-gaging station San Antonio River near Elmendorf (site 31) as part of the USGS National Water-Quality Assessment program (Bush and others, 2000).

In 2002, the USGS published results of a modeling project to simulate runoff and aquifer recharge and to estimate constituent loads in runoff on the Edwards aquifer outcrop and catchment area in northern Bexar County during 1997-2000 (Ockerman, 2002).

Data and results from these projects were compiled and incorporated into a watershed model to develop an improved understanding of the hydrology (sources of runoff and streamflow) and water quality (sources of constituent loads in streams) of the urban San Antonio area.

\section{Purpose and Scope}

This report describes the calibration of a Hydrological Simulation Program-FORTRAN (HSPF) watershed model used to simulate streamflow during 1997-2001 for the basins that compose the San Antonio River watershed in Bexar County. Also described is the use of HSPF-simulated streamflow with water-quality data collected in the area to estimate streamflow constituent loads at the outlet of the study area. Constituent loads were estimated for dissolved solids, nitrate plus nitrite nitrogen, suspended solids, and total lead. Data collected during 1992-2002 at 35 sampling sites in Bexar County and adjacent areas and data from other sources were compiled and used to calibrate and test the model and to estimate constituent loads. The types of data-collection sites used in this study include rainfall, streamflow, pan evaporation, and water quality (fig. 2, table 2).

\section{Description of Study Area}

The study area includes most of Bexar County and small areas of adjacent Atascosa and Medina Counties that drain to the San Antonio River (fig. 1). The San Antonio River watershed is subdivided into five basins-lower Medina River, Leon Creek, upper San Antonio River, Salado Creek, and lower San Antonio River. Parts of Calaveras Creek and Cibolo Creek Basins also are located in Bexar County. Cibolo Creek forms the boundary of Bexar County with Comal County on the north and with Guadalupe County on the east and flows into the San Antonio River downstream of the study area. Calaveras Creek, in southeastern Bexar County adjacent to Braunig Lake and outside the lower San Antonio River Basin, also flows to the San Antonio River downstream of the study area. These basins are not included in the study area and simulations.

The direction of drainage and streamflow in the study area generally is from northwest to southeast (fig. 1). The study area can be divided into four general hydrologic response areas on the basis of geology, soils, and runoff response to rainfall. The northern part of the study area includes $224 \mathrm{mi}^{2}$ of (1) Edwards aquifer catchment area and (2) Edwards aquifer outcrop (fig. 1). Both areas are characterized by thin, rocky soils and fairly steep slopes. The Edwards aquifer outcrop has greater permeability and infiltration of rainfall than the catchment area. Also, stream channels crossing the Edwards aquifer outcrop lose substantial flow to karst features such as fractures, sinkholes, and caves. Through central Bexar County, an area that comprises (3) the Edwards aquifer upper confining unit and Blackland Prairie consists of gently sloping, deep clayey soils characterized by slow to moderate rainfall infiltration rates and moderate to high water-holding capacity (U.S. Department of Agriculture, Soil Conservation Service, 1966). This area of Bexar County is highly developed and includes the urban San Antonio area. The southern part of the county is classified as (4) South Texas Plains (Texas State Historical Association, 2002). This part of the study area is level to rolling, has dense brush, and features a transition from clayey soils to more permeable loam and sandy soils.

Streamflow in the northern part of Bexar County is relatively infrequent because of high infiltration rates in the stream channels; even after heavy rains, streamflow might last only a few hours. In the central part of the county, base flow is evident, especially in wet weather. Two Edwards aquifer springs (San Pedro and San Antonio) also contribute flow to the San Antonio River (Brune, 1975). Flow is perennial in the lower San Antonio River in the southern part of Bexar County, largely because of discharge from wastewater treatment 
Table 2. Data-collection sites used for Hydrological Simulation Program—FORTRAN model calibration, testing, and simulations and estimation of water-quality constituent loads

[USGS, U.S. Geological Survey; NWS, National Weather Service; FM, Farm Road; IH, Interstate Highway]

\begin{tabular}{|c|c|c|c|c|}
\hline $\begin{array}{l}\text { Site } \\
\text { no. } \\
\text { (fig. 2) }\end{array}$ & $\begin{array}{l}\text { Name and } \\
\text { USGS station no. } \\
\text { (if applicable) }\end{array}$ & $\begin{array}{l}\text { Type of data } \\
\text { (no. of water- } \\
\text { quality samples, } \\
\text { if applicable) }\end{array}$ & $\begin{array}{l}\text { Data- } \\
\text { collection } \\
\text { period }\end{array}$ & Comment \\
\hline 1 & NWS station near Boerne, Tex. & Rainfall & $1997-2000$ & $\begin{array}{l}\text { Data used for calibration and simulation of Leon } \\
\text { Creek Basin }\end{array}$ \\
\hline 2 & NWS station near Bulverde, Tex. & Rainfall & $1997-2000$ & $\begin{array}{l}\text { Data used for calibration and simulation of Salado } \\
\text { Creek Basin }\end{array}$ \\
\hline 3 & $\begin{array}{l}\text { NWS station at San Antonio International } \\
\text { Airport, San Antonio, Tex. }\end{array}$ & Rainfall & $1997-2001$ & $\begin{array}{l}\text { Data used for calibration and simulation of Salado } \\
\text { Creek, Leon Creek, and upper and lower San } \\
\text { Antonio River Basins }\end{array}$ \\
\hline 4 & $\begin{array}{l}\text { NWS station at Sea World, San Antonio, } \\
\text { Tex. }\end{array}$ & Pan evaporation & $1997-2001$ & $\begin{array}{l}\text { Data used for calibration and simulation of all San } \\
\text { Antonio River watershed models }\end{array}$ \\
\hline 5 & 08181400 Helotes Creek at Helotes, Tex. & $\begin{array}{l}\text { Rainfall, } \\
\text { streamflow, and } \\
\text { water quality (6) }\end{array}$ & $1997-2001$ & $\begin{array}{l}\text { Rainfall and streamflow data used for calibration } \\
\text { and simulation of Leon Creek Basin; water- } \\
\text { quality data used to characterize runoff- } \\
\text { undeveloped land use }\end{array}$ \\
\hline 6 & $\begin{array}{l}08180945 \text { Leon Creek at Scenic Loop Rd. } \\
\text { near Leon Springs, Tex. }\end{array}$ & $\begin{array}{l}\text { Rainfall and } \\
\text { water quality (1) }\end{array}$ & $2001-02$ & $\begin{array}{l}\text { Rainfall data used for calibration and simulation of } \\
\text { Leon Creek Basin; water-quality data used to } \\
\text { characterize runoff-undeveloped land use }\end{array}$ \\
\hline 7 & $\begin{array}{l}08180941 \text { Government Canyon Creek site } 2 \\
\text { near Helotes, Tex. }\end{array}$ & $\begin{array}{l}\text { Rainfall and } \\
\text { water quality (5) }\end{array}$ & $1997-2001$ & $\begin{array}{l}\text { Rainfall data used for calibration and simulation of } \\
\text { Leon Creek and lower Medina River Basins; } \\
\text { water-quality data used to characterize runoff- } \\
\text { undeveloped land use }\end{array}$ \\
\hline 8 & $\begin{array}{l}08178627 \text { Elm Waterhole Creek Tributary } \\
\text { at San Antonio, Tex. }\end{array}$ & $\begin{array}{l}\text { Rainfall and } \\
\text { water quality ( } 3)\end{array}$ & $2001-02$ & $\begin{array}{l}\text { Rainfall data used for calibration and simulation of } \\
\text { Salado Creek Basin; water-quality data used to } \\
\text { characterize runoff-undeveloped land use }\end{array}$ \\
\hline 9 & $\begin{array}{l}08178595 \text { Stone Mountain drainage } \\
\text { channel at Granite Path, San Antonio, } \\
\text { Tex. }\end{array}$ & $\begin{array}{l}\text { Rainfall and } \\
\text { water quality (12) }\end{array}$ & 1996-2001 & $\begin{array}{l}\text { Rainfall data used for calibration and simulation of } \\
\text { Salado Creek Basin; water-quality data used to } \\
\text { characterize runoff-residential land use }\end{array}$ \\
\hline 10 & 08185000 Cibolo Creek at Selma, Tex. & Rainfall & $1997-2000$ & $\begin{array}{l}\text { Data used for calibration and simulation of Salado } \\
\text { Creek Basin }\end{array}$ \\
\hline 11 & $\begin{array}{l}08181425 \text { Cedar Elm Outfall at Huebner } \\
\text { Creek Tributary, San Antonio, Tex. }\end{array}$ & $\begin{array}{l}\text { Rainfall and } \\
\text { water quality (13) }\end{array}$ & 1996-2001 & $\begin{array}{l}\text { Rainfall data used for calibration and simulation of } \\
\text { Leon Creek Basin; water-quality data used to } \\
\text { characterize runoff-commercial land use }\end{array}$ \\
\hline 12 & $\begin{array}{l}08177600 \text { Olmos Creek Tributary at FM } \\
1535 \text { at Shavano Park, Tex. }\end{array}$ & $\begin{array}{l}\text { Rainfall and } \\
\text { water quality (5) }\end{array}$ & 1997-98 & $\begin{array}{l}\text { Rainfall data used for calibration and simulation of } \\
\text { Leon Creek Basin; water-quality data used to } \\
\text { characterize runoff- residential land use }\end{array}$ \\
\hline 13 & $\begin{array}{l}08178690 \text { Salado Creek Tributary at Bitters } \\
\text { Rd. at San Antonio, Tex. }\end{array}$ & Water quality (30) & 1992-2001 & $\begin{array}{l}\text { Data used to characterize runoff-residential land } \\
\text { use }\end{array}$ \\
\hline 14 & $\begin{array}{l}08178420 \text { Bandera Rd. Outfall at } \\
\text { Zarzamora Creek, San Antonio, Tex. }\end{array}$ & Water quality (23) & $1992-2000$ & $\begin{array}{l}\text { Data used to characterize runoff-commercial land } \\
\text { use }\end{array}$ \\
\hline 15 & $\begin{array}{l}08177720 \text { Olmos Creek Outfall at San } \\
\text { Pedro Ave., San Antonio, Tex. }\end{array}$ & Water quality (21) & 1992-2001 & $\begin{array}{l}\text { Data used to characterize runoff-commercial land } \\
\text { use }\end{array}$ \\
\hline 16 & $\begin{array}{l}08181440 \text { Ingram Rd. Outfall at Leon } \\
\text { Creek Tributary at San Antonio, Tex. }\end{array}$ & Water quality (23) & $1993-2000$ & $\begin{array}{l}\text { Data used to characterize runoff-transportation } \\
\text { corridor }\end{array}$ \\
\hline 17 & $\begin{array}{l}08178430 \text { Zarzamora Creek Outfall at } \\
\text { Alderette Park, San Antonio, Tex. }\end{array}$ & Water quality (13) & 1993-2000 & $\begin{array}{l}\text { Data used to characterize runoff-residential land } \\
\text { use }\end{array}$ \\
\hline 18 & $\begin{array}{l}08178820 \text { Rosillo Creek Tributary near } \\
\text { Rittiman Rd., San Antonio, Tex. }\end{array}$ & Water quality (29) & 1992-2001 & $\begin{array}{l}\text { Data used to characterize runoff-industrial land } \\
\text { use }\end{array}$ \\
\hline 19 & $\begin{array}{l}08178520 \text { Harlandale Creek Outfall at } \\
\text { South Flores St., San Antonio, Tex. }\end{array}$ & Water quality (24) & 1992-2001 & $\begin{array}{l}\text { Data used to characterize runoff-residential land } \\
\text { use }\end{array}$ \\
\hline
\end{tabular}


Table 2. Data-collection sites used for Hydrological Simulation Program-FORTRAN model calibration, testing, and simulations and estimation of water-quality constituent loads-Continued

\begin{tabular}{|c|c|c|c|c|}
\hline $\begin{array}{l}\text { Site } \\
\text { no. } \\
\text { (fig. 2) }\end{array}$ & $\begin{array}{l}\text { Name and } \\
\text { USGS station no. } \\
\text { (if applicable) }\end{array}$ & $\begin{array}{l}\text { Type of data } \\
\text { (no. of water- } \\
\text { quality samples, } \\
\text { if applicable) }\end{array}$ & $\begin{array}{l}\text { Data- } \\
\text { collection } \\
\text { period }\end{array}$ & Comment \\
\hline 20 & $\begin{array}{l}08177818 \text { San Antonio Springs at San } \\
\text { Antonio, Tex. }\end{array}$ & Streamflow & $1997-2001$ & $\begin{array}{l}\text { Data used for calibration and simulation of } \\
\text { springflow from San Antonio Springs in upper } \\
\text { San Antonio River Basin model }\end{array}$ \\
\hline 21 & $\begin{array}{l}08178090 \text { San Pedro Springs at San } \\
\text { Antonio, Tex. }\end{array}$ & Streamflow & $1997-2001$ & $\begin{array}{l}\text { Data used for calibration and simulation of } \\
\text { springflow from San Pedro Springs in upper } \\
\text { San Antonio River Basin model }\end{array}$ \\
\hline 22 & $\begin{array}{l}08178700 \text { Salado Creek at Loop } 410 \text { at San } \\
\text { Antonio, Tex. }\end{array}$ & Streamflow & 1997-2001 & $\begin{array}{l}\text { Data used for calibration of Salado Creek Basin } \\
\text { model }\end{array}$ \\
\hline 23 & $\begin{array}{l}08178050 \text { San Antonio River at Mitchell } \\
\text { St., San Antonio, Tex. }\end{array}$ & Streamflow & 1997-2001 & $\begin{array}{l}\text { Data used for calibration of upper San Antonio } \\
\text { River Basin model }\end{array}$ \\
\hline 24 & $\begin{array}{l}08178800 \text { Salado Creek at Loop } 13 \text { at San } \\
\text { Antonio, Tex. }\end{array}$ & $\begin{array}{l}\text { Streamflow and } \\
\text { water quality ( } 80)\end{array}$ & $1992-2001$ & $\begin{array}{l}\text { Streamflow data used for calibration of Salado } \\
\text { Creek Basin model; water-quality data used to } \\
\text { characterize base-flow quality }\end{array}$ \\
\hline 25 & $\begin{array}{l}08178565 \text { San Antonio River at Loop } 410 \\
\text { at San Antonio, Tex. }\end{array}$ & $\begin{array}{l}\text { Streamflow and } \\
\text { water quality (26) }\end{array}$ & $1992-2001$ & $\begin{array}{l}\text { Streamflow data used for calibration of upper San } \\
\text { Antonio River Basin model; water-quality data } \\
\text { used to characterize base-flow quality }\end{array}$ \\
\hline 26 & $\begin{array}{l}08181480 \text { Leon Creek at IH-35 at San } \\
\text { Antonio, Tex. }\end{array}$ & $\begin{array}{l}\text { Streamflow and } \\
\text { water quality ( } 24)\end{array}$ & 1992-2001 & $\begin{array}{l}\text { Streamflow data used for calibration of Leon } \\
\text { Creek Basin model; water-quality data used to } \\
\text { characterize base-flow quality }\end{array}$ \\
\hline 27 & 08180640 Medina River at La Coste, Tex. & $\begin{array}{l}\text { Streamflow and } \\
\text { water quality ( } 34)\end{array}$ & $1997-2000$ & $\begin{array}{l}\text { Streamflow data used for calibration and } \\
\text { simulation of lower Medina River Basin model; } \\
\text { water-quality data used to characterize water } \\
\text { quality of upper Medina River inflow }\end{array}$ \\
\hline 28 & $\begin{array}{l}08180700 \text { Medina River near Macdona, } \\
\text { Tex. }\end{array}$ & $\begin{array}{l}\text { Streamflow and } \\
\text { water quality ( } 34)\end{array}$ & $1997-2001$ & $\begin{array}{l}\text { Streamflow data used for calibration of lower } \\
\text { Medina River Basin model; water-quality data } \\
\text { used to characterize water quality of upper } \\
\text { Medina River inflow }\end{array}$ \\
\hline 29 & $\begin{array}{l}08180800 \text { Medina River near Somerset, } \\
\text { Tex. }\end{array}$ & Streamflow & 1997-2001 & $\begin{array}{l}\text { Data used for calibration of lower Medina River } \\
\text { Basin model }\end{array}$ \\
\hline 30 & $\begin{array}{l}08181500 \text { Medina River at San Antonio, } \\
\text { Tex. }\end{array}$ & $\begin{array}{l}\text { Streamflow and } \\
\text { water quality }(7)\end{array}$ & $1997-2001$ & $\begin{array}{l}\text { Streamflow data used for calibration of Medina } \\
\text { River Basin model; water-quality data used to } \\
\text { estimate streamflow constituent loads for } 1997- \\
2001 \text { simulations }\end{array}$ \\
\hline 31 & $\begin{array}{l}08181800 \text { San Antonio River near } \\
\text { Elmendorf, Tex. }\end{array}$ & $\begin{array}{l}\text { Streamflow and } \\
\text { water quality (106) }\end{array}$ & 1992-2001 & $\begin{array}{l}\text { Streamflow data used for calibration of lower San } \\
\text { Antonio River Basin model; water-quality data } \\
\text { used to estimate streamflow constituent loads } \\
\text { for 1997-2001 simulations }\end{array}$ \\
\hline 32 & $\begin{array}{l}\text { USGS sampling site } 291407098243701 \\
\text { Medio Creek WWRC Outfall at San } \\
\text { Antonio, Tex. }\end{array}$ & Water quality (35) & 1992-95 & $\begin{array}{l}\text { Data used to characterize recycled wastewater } \\
\text { quality }\end{array}$ \\
\hline 33 & $\begin{array}{l}\text { USGS sampling site } 291632098305001 \\
\text { Leon Creek WWRC Outfall at San } \\
\text { Antonio, Tex. }\end{array}$ & Water quality (34) & 1992-95 & $\begin{array}{l}\text { Data used to characterize recycled wastewater } \\
\text { quality }\end{array}$ \\
\hline 34 & $\begin{array}{l}\text { USGS sampling site } 291655098253601 \\
\text { Salado Creek WWRC Outfall at San } \\
\text { Antonio, Tex. }\end{array}$ & Water quality (35) & 1992-95 & $\begin{array}{l}\text { Data used to characterize recycled wastewater } \\
\text { quality }\end{array}$ \\
\hline 35 & $\begin{array}{l}\text { USGS sampling site } 292354098400701 \\
\text { Dos Rios WWRC Outfall at San } \\
\text { Antonio, Tex. }\end{array}$ & Water quality (27) & 1992-95 & $\begin{array}{l}\text { Data used to characterize recycled wastewater } \\
\text { quality }\end{array}$ \\
\hline
\end{tabular}




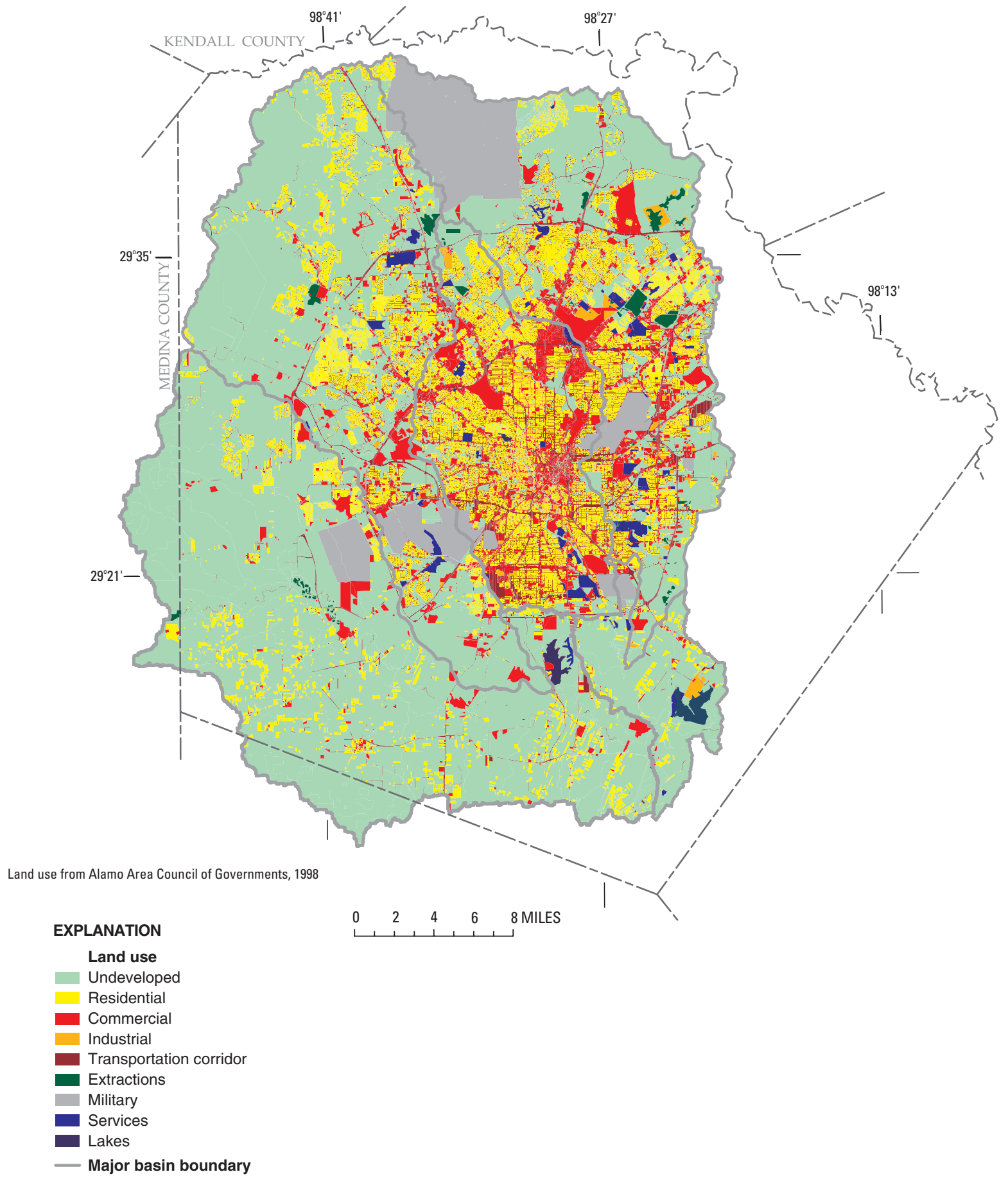

Figure 3. Study area land use, Bexar County, Texas.

plants and inflow originating from the upper Medina River.

Land use in the study area for 1998 is shown in figure 3 (David Kruse, Alamo Area Council of Governments, written commun., 1999). The estimated 2001 population in Bexar County is 1,418,000 (U.S. Census Bureau, 2002). Development in Bexar County has occurred rapidly over the past decade, with a population increase of 17.5 percent during 1990-2000 (U.S. Census Bureau, 2002). 
Four major municipal wastewater-recycling centers (WWRCs) discharge about 120 million gallons per day to Leon Creek and the lower Medina and San Antonio Rivers (table 3). There also are several smaller treatment facilities, including military and industrial dischargers. These smaller discharges, combined, are less than 2 percent of the total wastewater flow and are not included in the model simulations. Data for recycled water discharges were obtained from the Texas Natural Resource Conservation Commission (Michael Veazey, written commun., 2001).

\section{Description of Simulation Model, Modeling Process, and Loads Estimation Method}

The HSPF (Bicknell and others, 1997) is a continuous-simulation model using a conceptual framework to represent infiltration, evaporation, interception storage, surface runoff, interflow (water that infiltrates into the soil and moves laterally through the upper soil horizons until it returns to the surface, often in a stream channel), and base flow on a pervious land segment (PERLND); and to represent retention storage and surface runoff on an impervious land segment (IMPLND). Each user-defined land segment represents its own unique hydrologic response system on the basis of soil type, land cover, basin slope, or other important basin characteristic. These land segments do not need to be contiguous within the model. The runoff from each land segment is moved through a system of channel or reservoir reaches (RCHRES) using storage routing.

The HSPF model uses input from three types of data: time series, basin-related model parameters, and process-related model parameters. Continuous time series of precipitation and potential evaporation are needed to run the model. Point-precipitation data, measured by rain gages, are assumed to be uniform

Table 3. Major recycled wastewater discharges, Bexar County, Texas

\begin{tabular}{llc}
\hline $\begin{array}{c}\text { Recycling } \\
\text { facility }\end{array}$ & \multicolumn{1}{c}{$\begin{array}{c}\text { Discharge } \\
\text { site }\end{array}$} & $\begin{array}{c}\text { Average daily } \\
\text { discharge } \\
\text { (million } \\
\text { gallons } \\
\text { per day) }\end{array}$ \\
\hline Medio Creek & Medio Creek (Medina River) & 4.89 \\
Leon Creek & Leon Creek & 34.4 \\
Dos Rios & Lower Medina River & 53.8 \\
Salado Creek & Lower San Antonio River & 31.0 \\
\hline
\end{tabular}

over a land segment. Potential evaporation data can be estimated from measured pan evaporation or computed using minimum and maximum daily temperatures. Time series of measured streamflow are used for model calibration and testing.

The six basin-related model parameters (table 4) define the areal extent of each land segment, the reach length, and a table of values (FTABLE) of surface area, volume, and discharge, as a function of depth for each reach or reservoir of the watershed. These parameters represent the physical characteristics of each land segment or reach of a basin and generally remain unchanged during calibration of the model.

The 21 process-related model parameters (table 5) represent the physical processes of soil infiltration, soil moisture, evapotranspiration (ET), interception storage of plants, interflow recession, groundwater recession, and surface runoff for each land segment. The process-related model parameters for each land segment are adjusted to calibrate the model. Some process-related parameters can be automatically adjusted by month to account for seasonal variations: interception storage capacity (CEPSC), interflow inflow (INTFW), interflow recession rate (IRC), lowerzone ET (LZETP), Manning's n for assumed overland flow plane (NSUR), and upper-zone nominal storage (UZSN). For this study, monthly variation of these parameters were not investigated or implemented primarily because of insufficient data to characterize monthly variations in the parameters. The HSPF users manual (Bicknell and others, 1997) provides a more complete description of each parameter.

Table 4. Basin-related model parameters for the Hydrological Simulation Program-FORTRAN

[PERLND, pervious land segment; IMPLND, impervious land segment; FTABLE, table of depth, surface area, volume, and discharge for each stream reach]

\begin{tabular}{ll}
\hline Parameter & \multicolumn{1}{c}{$\begin{array}{c}\text { Description } \\
\text { (units) }\end{array}$} \\
\hline AREA & $\begin{array}{c}\text { Drainage area of each PERLND or IMPLND } \\
\text { (acres) }\end{array}$ \\
LEN & Stream reach length (miles) \\
DEPTH & FTABLE depth (feet) \\
SAREA & FTABLE surface area (acres) \\
VOL & FTABLE volume (acre-feet) \\
DISCH & FTABLE discharge (cubic feet per second) \\
\hline
\end{tabular}


Table 5. Process-related model parameters for the Hydrological Simulation Program—FORTRAN [--, none; ET, evapotranspiration]

\begin{tabular}{|c|c|c|c|c|c|}
\hline Parameter & Description $^{1}$ & Default & Minimum & Maximum & Units \\
\hline AGWS & Initial active ground-water storage & -- & 0 & -- & inches \\
\hline AGWETP & Available ET satisfied by active ground water & 0 & 0 & 1.0 & -- \\
\hline AGWRC & Active ground-water recession rate & -- & .001 & 1.0 & per day \\
\hline BASETP & Available ET satisfied by base flow & 0 & 0 & 1.0 & -- \\
\hline CEPSC & Interception storage capacity & 0 & 0 & 1.0 & inches \\
\hline DEEPFR & Fraction of inflow that enters inactive ground water & 0 & 0 & 1.0 & -- \\
\hline INFEXP & Infiltration equation exponent & 2.0 & 0 & 10.0 & -- \\
\hline INFILD & Ratio of maximum to mean infiltration capacities & 2.0 & 1.0 & 2.0 & -- \\
\hline INFILT & Index to infiltration capacity of soil & -- & .0001 & 100.0 & inches per hour \\
\hline INTFW & Interflow inflow & -- & 0 & -- & -- \\
\hline IRC & Interflow recession rate & -- & 0 & 1.0 & per day \\
\hline KVARY & Nonexponential ground-water recession rate & 0 & 0 & -- & per inch \\
\hline LSUR & Length of assumed overland flow plane & -- & 1.0 & -- & feet \\
\hline LZETP & Lower-zone ET & 0 & 0 & 1.0 & -- \\
\hline LZS & Initial lower-zone storage & -- & 0 & -- & inches \\
\hline LZSN & Lower-zone nominal storage & -- & .01 & 100.0 & inches \\
\hline NSUR & Manning's $n$ for assumed overland flow plane & .1 & .001 & 1.0 & -- \\
\hline RETSC & Impervious retention storage capacity & 0 & 0 & 10.0 & inches \\
\hline SLSUR & Slope of assumed overland flow plane & -- & .000001 & 10.0 & feet per foot \\
\hline UZS & Initial upper-zone storage & -- & 0 & -- & inches \\
\hline UZSN & Upper-zone nominal storage & -- & .01 & 10.0 & inches \\
\hline
\end{tabular}

${ }^{1}$ The users manual for Hydrological Simulation Program_FORTRAN (Bicknell and others, 1997) provides a more complete description of each parameter.

The HSPEXP (Lumb and others, 1994) computerized expert system was used to help adjust process-related parameters to achieve improved model calibration. HSPEXP is a stand-alone program that incorporates HSPF. The HSPEXP procedures consist of a set of hierarchical rules designed to guide the calibration of the model(s) through a systematic evaluation of the model parameters.

Loads of selected constituents (dissolved solids, nitrate plus nitrite nitrogen, suspended solids, and total lead) were estimated by applying source concentrations to HSPF-derived flow volumes to compute constituent loads by source and land-use category. HSPF model land segments (PERLNDs and
IMPLNDs) usually are configured according to land use, geology, soil type, slope, and other characteristics that affect the hydrologic response to rainfall. For the San Antonio River watershed, model segments also were configured according to land-use categories or other sources of flow that might have different runoffquality characteristics. In addition, HSPF includes the capability to assign water originating from various sources to unique categories as it moves through the simulation process. For example, runoff from all commercial land-use areas can be assigned an exclusive category and can be accounted for separately from other categories (such as residential, transportation, or even recycled water discharged from treatment plants) as it 
moves through the watershed. Therefore, simulated streamflow at any point in the model can be separated into components of flow that originate from various sources. To estimate loads, water-quality concentrations characteristic of each source of flow were applied to the appropriate flow volumes to compute streamflow loads.

\section{SIMULATION OF STREAMFLOW}

\section{Model Calibration and Testing}

The HSPF model for each of the five basins of the San Antonio River watershed was calibrated and tested separately. All five models were calibrated using 19972001 data (table 2). Data from 2001 were used independently to test the calibration of each model. Sensitivity analyses were done for selected parameters for each model to assess the effects of parameter uncertainty on simulated flow.

The first step in developing an HSPF model for each basin was to divide it into RCHRES segments, taking into consideration the stream and reservoir (floodcontrol impoundment) configuration of each basin. After subdivision, each basin contained from 4 to 36 RCHRES segments for a total of 103. Stream channel characteristics (surface area, volume, and discharge as a function of depth) were determined for each of the model stream reaches and entered in HSPF FTABLES (tables of stream channel parameters). For gaged stream reaches, FTABLE parameters were based on discharge measurements made at USGS gaging stations. FTABLE information for ungaged reaches were estimated from similar gaged reaches. FTABLES for flood-impoundment reservoirs were developed from the dam and reservoir design specifications.

PERLND (pervious) and IMPLND (impervious) land segments were configured according to geologysoil characteristics and land use. Four primary physiographic categories (fig. 1) are: (1) Edwards aquifer catchment area (relatively low permeability); (2) Edwards aquifer outcrop (relatively high permeability); (3) Edwards aquifer upper confining unitBlackland Prairie (deeper clay soils and moderate permeability); and (4) South Texas Plains (loam and sandy soils and high permeability). Land-use categories comprise undeveloped, residential, commercial, transportation, industrial, services (mostly public parks), quarries, and military. Table 6 lists areas of PERLNDs and IMPLNDs for each basin, by land-use category. For model simulation, various military land segments were re-categorized as the most similar land cover (for example, undeveloped rangeland or industrial), resulting in 28 PERLNDS (table 7).

Models were calibrated by adjusting various process-related parameters so that simulated streamflow corresponded to gaged streamflow in the basin, considering such criteria as error in total streamflow volume for the calibration period, low-flow and highflow distribution, and error in flow volumes for selected storms. A summary of process-related parameters for the calibrated models is shown in table 7.

\section{Lower Medina River Basin}

The lower Medina River Basin $\left(306 \mathrm{mi}^{2}\right)$ and its subdivision into RCHRES segments are shown in figure 4. The upper Medina River Basin, including Medina Lake, is not included in the model. Medina River streamflow entering the lower watershed was input (as a boundary condition) to the model according to streamflow records from USGS streamflow-gaging station Medina River at La Coste (08180640). Small parts of the basin also extend into Medina and Atascosa Counties (fig. 4).

Besides the station at La Coste (discontinued in 2001), USGS streamflow-gaging stations are on the Medina River near Macdona (08180700), near Somerset (08180800), and at San Antonio (08181500). Data collected from the Macdona and Somerset stations were used to help calibrate the parts of the model representing drainage upstream of the respective stations. The San Antonio station is the primary station used for calibration of the model. The Medina River Basin model also includes inflow from the Leon Creek Basin that occurs upstream of the San Antonio station. For calibration, gaged inflow from Leon Creek was used as input to the model; for subsequent simulations and analysis, simulated Leon Creek streamflow data were used as input.

An annual comparison of measured and simulated streamflow is shown in table 8. Overall error in simulated streamflow for the calibration period (19972000) was -4.3 percent; 1999 and 2000 were undersimulated (-16.8 and -21.7 percent error, respectively). The 2001 testing results oversimulated volume by 6.8 percent. Overall error for 1997-2001 was -2.9 percent. A comparison of measured and simulated (7-day mean) streamflow at the Medina River at San Antonio is shown in figure 5. 


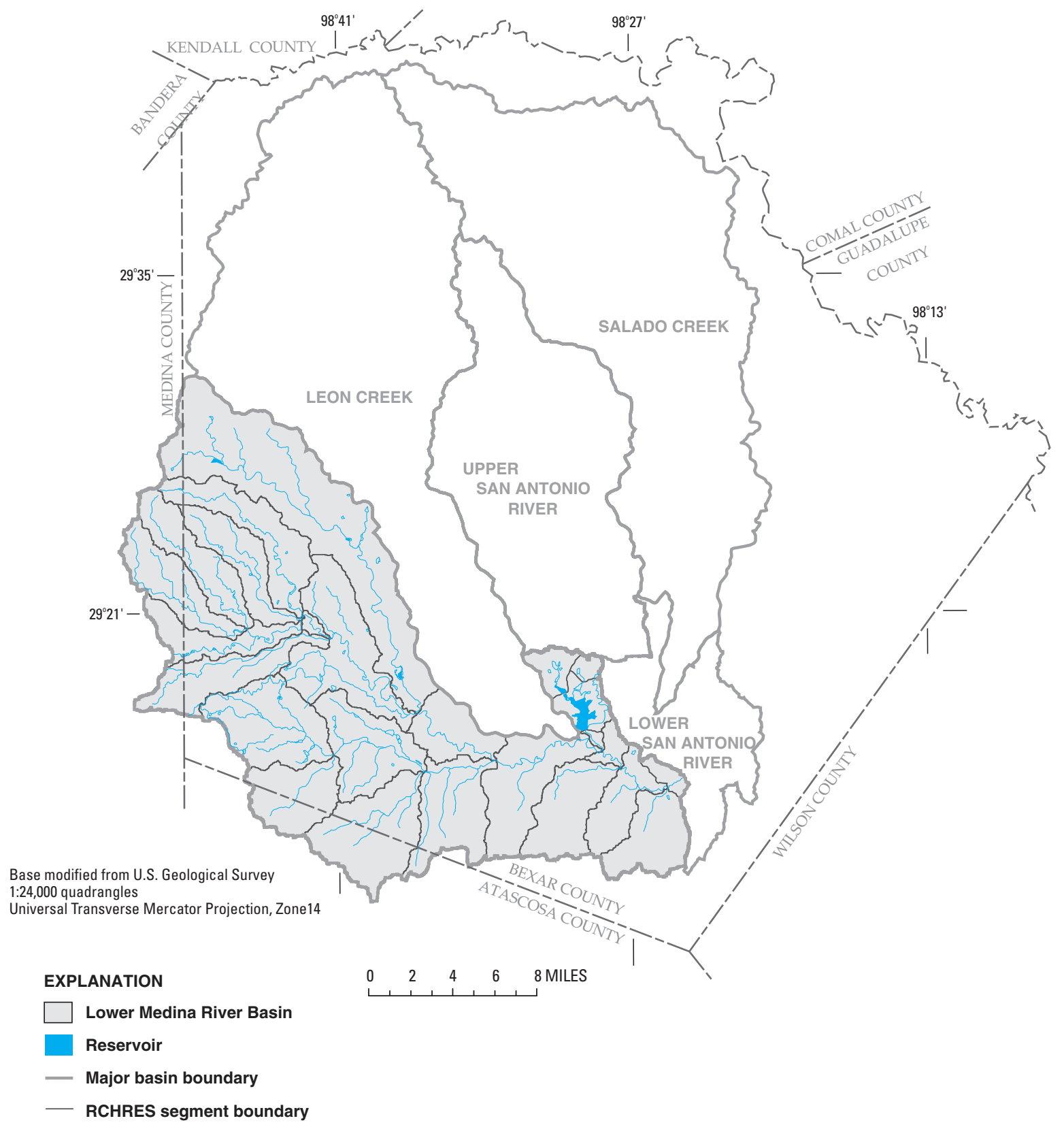

Figure 4. Lower Medina River Basin stream and reservoir (RCHRES) segments.

\section{Leon Creek Basin}

The Leon Creek Basin and its subdivision into RCHRES segments are shown in figure 6. The upper $219 \mathrm{mi}^{2}$ of the $237-\mathrm{mi}^{2}$ basin is gaged by USGS streamflow-gaging station Leon Creek at IH-35 at San Antonio (08181480). The Helotes Creek Basin $\left(15 \mathrm{mi}^{2}\right)$ in the upper part of the Leon Creek Basin also is gaged (Helotes Creek at Helotes [08181400]). Data collected from the Leon Creek station are the primary source of data used to calibrate the Leon Creek Basin model. HSPF parameters obtained from the gaged part of the basin were applied to the ungaged part to estimate streamflow for the entire basin.

Overall error in simulated streamflow for the calibration period (1997-2000) was -9.2 percent (table 8); 1997 and 1998 results (-8.7 and -14.2 percent error, respectively) were influenced by rather extreme events (June 1997 and October 1998) that were undersimulated. Simulated streamflow for 1999 (a dry year) and 

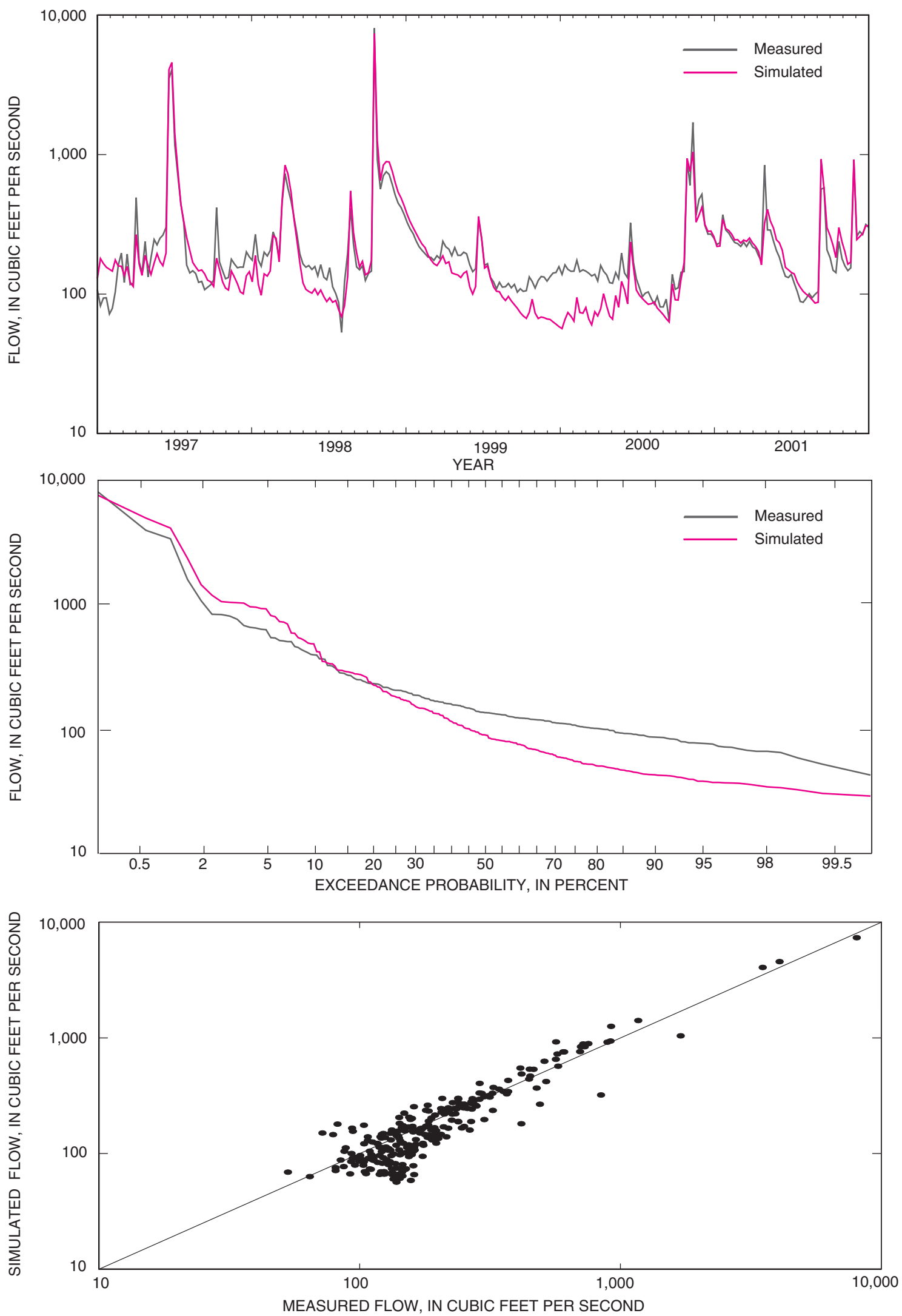

Figure 5. Measured and simulated 7-day mean streamflow at Medina River at San Antonio, Texas (08181500), 1997-2001.

12 Simulation of Streamflow and Estimation of Streamflow Constituent Loads in the San Antonio River Watershed, Bexar County, Texas, 1997-2001 
Table 6. Pervious and impervious land segment areas for basins in the San Antonio River watershed, Bexar County, Texas

[In acres; A, Edwards aquifer catchment area; --, not applicable; B, Edwards aquifer outcrop; C, Edwards aquifer upper confining unit-Blackland Prairie; D, South Texas Plains]

\begin{tabular}{|c|c|c|c|c|c|}
\hline \multirow{2}{*}{$\begin{array}{l}\text { Land-use } \\
\text { category }\end{array}$} & \multicolumn{5}{|c|}{ Basin } \\
\hline & $\begin{array}{c}\text { Lower } \\
\text { Medina River }\end{array}$ & Leon Creek & $\begin{array}{c}\text { Upper San } \\
\text { Antonio River }\end{array}$ & Salado Creek & $\begin{array}{c}\text { Lower San } \\
\text { Antonio River }\end{array}$ \\
\hline \multicolumn{6}{|c|}{ PERLND (pervious land segment) } \\
\hline Undeveloped, A & - & 36,756 & -- & 21,315 & -- \\
\hline Undeveloped, B & -- & 18,392 & 2,897 & 32,882 & -- \\
\hline Undeveloped, C & 94,142 & 46,803 & 9,398 & 26,211 & 10,913 \\
\hline Undeveloped, D & 73,569 & -- & -- & -- & 10,090 \\
\hline Residential, A & -- & 7,470 & -- & 1,440 & -- \\
\hline Residential, B & -- & 1,211 & 1,150 & 4,587 & -- \\
\hline Residential, C & 6,256 & 8,632 & 23,110 & 16,197 & 1,103 \\
\hline Residential, D & 6,691 & -- & -- & -- & 902 \\
\hline Commercial, A & -- & 708 & -- & 5 & -- \\
\hline Commercial, B & -- & 496 & 82 & 800 & -- \\
\hline Commercial, $\mathrm{C}$ & 2,269 & 3,859 & 9,151 & 5,071 & 299 \\
\hline Commercial, D & 539 & -- & -- & -- & 95 \\
\hline Transportation, A & -- & 1,163 & -- & 63 & -- \\
\hline Transportation, B & -- & 526 & 251 & 1,414 & -- \\
\hline Transportation, C & 792 & 2,812 & 7,556 & 796 & 118 \\
\hline Transportation, D & 481 & -- & -- & -- & 177 \\
\hline Industrial, A & -- & 0 & -- & 0 & -- \\
\hline Industrial, B & -- & 0 & 155 & 0 & -- \\
\hline Industrial, C & 8 & 3,071 & 374 & 4,276 & 6 \\
\hline Industrial, D & 1 & -- & -- & -- & 515 \\
\hline Services, A & -- & 0 & -- & 0 & -- \\
\hline Services, B & -- & 528 & 79 & 488 & -- \\
\hline Services, C & 143 & 590 & 1,432 & 2,160 & 894 \\
\hline Services, D & 0 & -- & -- & -- & 230 \\
\hline Quarries, A & -- & 300 & -- & 0 & -- \\
\hline Quarries, B & -- & 421 & 215 & 659 & -- \\
\hline Quarries, C & 339 & 0 & 0 & 1,206 & 0 \\
\hline Quarries, D & 0 & -- & -- & -- & -- \\
\hline Military, A & -- & 849 & -- & 0 & -- \\
\hline Military, B & -- & 0 & 0 & 0 & -- \\
\hline Military, C & 2,948 & 841 & 1,018 & 2,323 & 0 \\
\hline Military, D & 0 & -- & -- & -- & -- \\
\hline \multicolumn{6}{|c|}{ IMPLND (impervious land segment) } \\
\hline Residential & 2,283 & 5,121 & 6,065 & 4,235 & 214 \\
\hline Commercial & 2,809 & 4,709 & 9,233 & 63 & 132 \\
\hline Transportation & 1,274 & 2,982 & 7,807 & 2,378 & 127 \\
\hline Industrial & 6 & 1,074 & 353 & 4,276 & 108 \\
\hline Services & 36 & 589 & 168 & 485 & 203 \\
\hline Quarries & 18 & 0 & 11 & 63 & 0 \\
\hline Military & 983 & 561 & 1,244 & 1,117 & 0 \\
\hline
\end{tabular}


$\vec{\perp} \quad$ Table 7. Selected annual PERLND and IMPLND process-related parameters for flow, San Antonio River watershed models, Bexar County, Texas

[Parameter definitions and units in table 5; PERLND, pervious land segment; A, Edwards aquifer catchment area; --, not applicable; B, Edwards aquifer outcrop; C, Edwards aquifer upper confining unit-Blackland Prairie; D, South Texas Plains; IMPLND, impervious land segment]

\begin{tabular}{|c|c|c|c|c|c|c|c|c|c|c|c|c|c|c|c|c|}
\hline Land-use category & AGWETP & AGWRC & BASETP & CEPSC & DEEPFR & INFILT & INTFW & IRC & KVARY & LSUR & LZETP & LZSN & NSUR & RETSC & SLSUR & UZSN \\
\hline \multicolumn{17}{|c|}{ Lower Medina River Basin } \\
\hline \multicolumn{17}{|l|}{ PERLND } \\
\hline Undeveloped, A & -- & -- & -- & -- & -- & -- & -- & -- & -- & -- & -- & -- & -- & -- & -- & -- \\
\hline Undeveloped, B & -- & -- & -- & -- & -- & -- & -- & -- & -- & -- & -- & -- & -- & -- & -- & -- \\
\hline Undeveloped, C & 0 & 0.90 & 0 & 0.30 & 0.40 & 0.60 & 0.20 & 0.50 & 0 & 800 & 0.40 & 2.0 & 0.25 & -- & $0.04-0.03$ & 0.70 \\
\hline Undeveloped, D & 0 & .98 & 0 & .30 & .30 & .70 & .50 & .60 & 0 & 800 & .40 & 2.0 & .25 & -- & $.03-.02$ & .70 \\
\hline \multirow{4}{*}{ 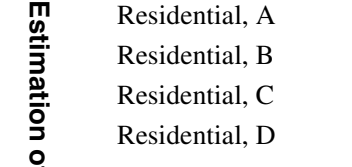 } & -- & -- & -- & -- & -- & -- & -- & -- & -- & -- & -- & -- & -- & -- & -- & -- \\
\hline & -- & -- & -- & -- & -- & -- & -- & -- & -- & -- & -- & -- & -- & -- & -- & -- \\
\hline & 0 & .90 & 0 & .35 & .40 & .60 & .20 & .50 & 0 & 800 & .40 & 2.0 & .25 & -- & $.04-.03$ & .70 \\
\hline & 0 & .98 & 0 & .30 & .30 & .70 & .50 & .60 & 0 & 800 & .40 & 2.0 & .25 & -- & $.03-.02$ & .70 \\
\hline \multirow{4}{*}{ 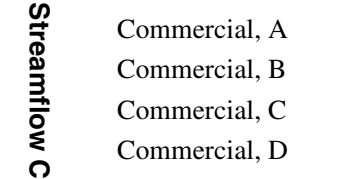 } & -- & -- & -- & -- & -- & -- & -- & -- & -- & -- & -- & -- & -- & -- & -- & -- \\
\hline & -- & -- & -- & -- & -- & -- & -- & -- & -- & -- & -- & -- & -- & -- & -- & -- \\
\hline & 0 & .90 & 0 & .30 & .40 & .60 & .20 & .50 & 0 & 800 & .40 & 2.0 & .25 & -- & $.04-.03$ & .70 \\
\hline & 0 & .98 & 0 & .30 & .30 & .70 & .50 & .60 & 0 & 800 & .40 & 2.0 & .25 & -- & $.03-.02$ & .70 \\
\hline \multirow{4}{*}{ 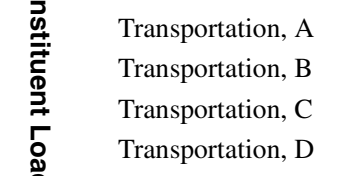 } & -- & -- & -- & -- & -- & -- & -- & -- & -- & -- & -- & -- & -- & -- & -- & -- \\
\hline & -- & -- & -- & -- & -- & -- & -- & -- & -- & -- & -- & -- & -- & -- & -- & -- \\
\hline & 0 & .90 & 0 & .25 & .40 & .60 & .20 & .50 & 0 & 800 & .40 & 2.0 & .25 & -- & $.04-.03$ & .70 \\
\hline & 0 & .98 & 0 & .25 & .30 & .70 & .50 & .60 & 0 & 800 & .40 & 2.0 & .25 & -- & $.03-.02$ & .70 \\
\hline \multirow{4}{*}{ 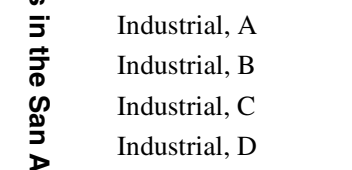 } & -- & -- & -- & -- & -- & -- & -- & -- & -- & -- & -- & -- & -- & -- & -- & -- \\
\hline & -- & -- & -- & -- & -- & -- & -- & -- & -- & -- & -- & -- & -- & -- & -- & -- \\
\hline & 0 & .90 & 0 & .25 & .40 & .60 & .20 & .50 & 0 & 800 & .40 & 2.0 & .25 & -- & .04-.03 & .70 \\
\hline & 0 & .98 & 0 & .25 & .30 & .70 & .50 & .60 & 0 & 800 & .40 & 2.0 & .25 & -- & $.03-.02$ & .70 \\
\hline \multirow{4}{*}{ 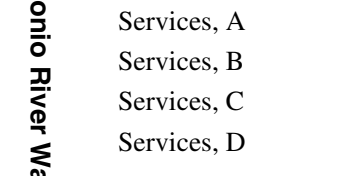 } & -- & -- & -- & -- & -- & -- & -- & -- & -- & -- & -- & -- & -- & -- & -- & -- \\
\hline & -- & -- & -- & -- & -- & -- & -- & -- & -- & -- & -- & -- & -- & -- & -- & -- \\
\hline & 0 & .90 & 0 & .25 & .40 & .60 & .20 & .50 & 0 & 800 & .40 & 2.0 & .25 & -- & $.04-.03$ & .70 \\
\hline & 0 & .98 & 0 & .25 & .30 & .70 & .50 & .60 & 0 & 800 & .40 & 2.0 & .25 & -- & $.03-.02$ & .70 \\
\hline Quarries, A & -- & -- & -- & -- & -- & -- & -- & -- & -- & -- & -- & -- & -- & -- & -- & -- \\
\hline Quarries, B & -- & -- & -- & -- & -- & -- & -- & -- & -- & -- & -- & -- & -- & -- & -- & -- \\
\hline Quarries, C & 0 & .90 & 0 & .25 & .40 & .60 & .20 & .50 & 0 & 800 & .40 & 2.0 & .25 & -- & $.04-.03$ & .70 \\
\hline Quarries, D & -- & -- & -- & -- & -- & -- & -- & -- & -- & -- & -- & -- & -- & -- & $.03-.02$ & -- \\
\hline \multicolumn{17}{|l|}{ IMPLND } \\
\hline All categories & -- & -- & -- & -- & -- & -- & -- & -- & -- & 800 & -- & -- & .10 & .30 & $.04-.02$ & -- \\
\hline
\end{tabular}


Table 7. Selected annual PERLND and IMPLND process-related parameters for flow, San Antonio River watershed models, Bexar County, TexasContinued

\begin{tabular}{|c|c|c|c|c|c|c|c|c|c|c|c|c|c|c|c|c|}
\hline Land-use category & AGWETP & AGWRC & BASETP & CEPSC & DEEPFR & INFILT & INTFW & IRC & KVARY & LSUR & LZETP & LZSN & NSUR & RETSC & SLSUR & UZSN \\
\hline \multicolumn{17}{|c|}{ Leon Creek Basin } \\
\hline \multicolumn{17}{|l|}{ PERLND } \\
\hline Undeveloped, A & 0 & 0.90 & 0 & 0.50 & 0.05 & 0.50 & 0.30 & 0.30 & 0 & 800 & 0.40 & 2.0 & 0.25 & -- & $0.15-0.04$ & 0.70 \\
\hline Undeveloped, B & 0 & .40 & 0 & .40 & .90 & .60 & .10 & .10 & 0 & 800 & .30 & 2.0 & .25 & -- & $.12-.04$ & .70 \\
\hline Undeveloped, C & 0 & .90 & 0 & .25 & .70 & .60 & .20 & .50 & 0 & 800 & .40 & 2.5 & .25 & -- & $.12-.04$ & .80 \\
\hline Undeveloped, D & -- & -- & -- & -- & -- & -- & -- & -- & -- & -- & -- & -- & -- & -- & -- & -- \\
\hline Residential, A & 0 & .90 & 0 & .50 & .05 & .50 & .30 & .30 & 0 & 800 & .40 & 2.0 & .25 & -- & $.15-.04$ & .70 \\
\hline Residential, B & 0 & .40 & 0 & .40 & .90 & .60 & .10 & .10 & 0 & 800 & .30 & 2.0 & .25 & -- & $.12-.04$ & .70 \\
\hline Residential, C & 0 & .90 & 0 & .25 & .70 & .60 & .20 & .50 & 0 & 800 & .40 & 2.5 & .25 & -- & $.12-.04$ & .80 \\
\hline Residential, D & -- & -- & -- & -- & -- & -- & -- & -- & -- & -- & -- & -- & -- & -- & -- & -- \\
\hline Commercial, A & 0 & .90 & 0 & .50 & .05 & .50 & .30 & .30 & 0 & 800 & .40 & 2.0 & .25 & -- & $.15-.04$ & .70 \\
\hline Commercial, B & 0 & .40 & 0 & .40 & .90 & .60 & .10 & .10 & 0 & 800 & .30 & 2.0 & .25 & -- & $.12-.04$ & .70 \\
\hline Commercial, C & 0 & .90 & 0 & .25 & .70 & .60 & .20 & .50 & 0 & 800 & .40 & 2.5 & .25 & -- & $.12-.04$ & .80 \\
\hline Commercial, D & -- & -- & -- & -- & -- & -- & -- & -- & -- & -- & -- & -- & -- & -- & -- & -- \\
\hline Transportation, A & 0 & .90 & 0 & .50 & .05 & .50 & .30 & .30 & 0 & 800 & .40 & 2.0 & .25 & -- & $.15-.04$ & .70 \\
\hline Transportation, B & 0 & .40 & 0 & .40 & .90 & .60 & .10 & .10 & 0 & 800 & .30 & 2.0 & .25 & -- & $.12-.04$ & .70 \\
\hline Transportation, C & 0 & .90 & 0 & .25 & .70 & .60 & .20 & .50 & 0 & 800 & .40 & 2.5 & .25 & -- & $.12-.04$ & .80 \\
\hline Transportation, D & -- & -- & -- & -- & -- & -- & -- & -- & -- & -- & -- & -- & -- & -- & -- & -- \\
\hline Industrial, A & 0 & .90 & 0 & .50 & .05 & .50 & .30 & .30 & 0 & 800 & .40 & 2.0 & .25 & -- & $.15-.04$ & .70 \\
\hline Industrial, B & 0 & .40 & 0 & .40 & .90 & .60 & .10 & .10 & 0 & 800 & .30 & 2.0 & .25 & -- & $.12-.04$ & .70 \\
\hline Industrial, C & 0 & .90 & 0 & .25 & .70 & .60 & .20 & .50 & 0 & 800 & .40 & 2.5 & .25 & -- & $.12-.04$ & .80 \\
\hline Industrial, D & -- & -- & -- & -- & -- & -- & -- & -- & -- & -- & -- & -- & -- & -- & -- & -- \\
\hline Services, A & 0 & .90 & 0 & .50 & .05 & .50 & .30 & .30 & 0 & 800 & .40 & 2.0 & .25 & -- & $.15-.04$ & .70 \\
\hline Services, B & 0 & .40 & 0 & .40 & .90 & .60 & .10 & .10 & 0 & 800 & .30 & 2.0 & .25 & -- & $.12-.04$ & .70 \\
\hline Services, C & 0 & .90 & 0 & .25 & .70 & .60 & .20 & .50 & 0 & 800 & .40 & 2.5 & .25 & -- & $.12-.04$ & .80 \\
\hline Services, D & -- & -- & -- & -- & -- & -- & -- & -- & -- & -- & -- & -- & -- & -- & -- & -- \\
\hline Quarries, A & 0 & .90 & 0 & .50 & .05 & .50 & .30 & .30 & 0 & 800 & .40 & 2.0 & .25 & -- & $.15-.04$ & .70 \\
\hline Quarries, B & 0 & .40 & 0 & .40 & .90 & .60 & .10 & .10 & 0 & 800 & .30 & 2.0 & .25 & -- & $.12-.04$ & .70 \\
\hline Quarries, C & 0 & .90 & 0 & .25 & .70 & .60 & .20 & .50 & 0 & 800 & .40 & 2.5 & .25 & -- & $.12-.04$ & .80 \\
\hline Quarries, D & -- & -- & -- & -- & -- & -- & -- & -- & -- & -- & -- & -- & -- & -- & -- & -- \\
\hline \multicolumn{17}{|l|}{ IMPLND } \\
\hline All categories & -- & -- & -- & -- & -- & -- & -- & -- & -- & 800 & -- & -- & .10 & 0.30 & $.10-.04$ & -- \\
\hline
\end{tabular}


๘ Table 7. Selected annual PERLND and IMPLND process-related parameters for flow, San Antonio River watershed models, Bexar County, TexasContinued

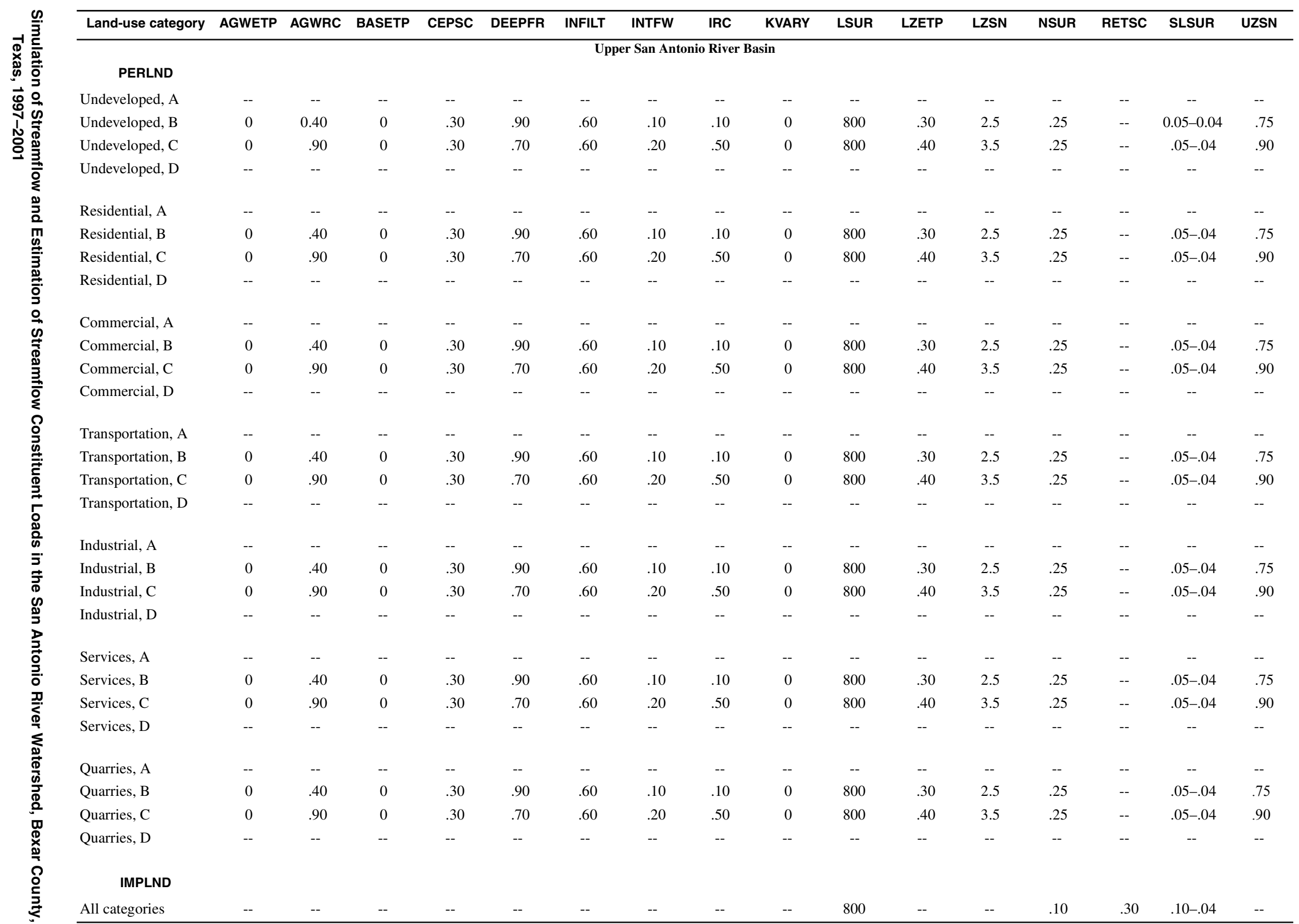


Table 7. Selected annual PERLND and IMPLND process-related parameters for flow, San Antonio River watershed models, Bexar County, TexasContinued

\begin{tabular}{|c|c|c|c|c|c|c|c|c|c|c|c|c|c|c|c|c|}
\hline Land-use category & AGWETP & AGWRC & BASETP & CEPSC & DEEPFR & INFILT & INTFW & IRC & KVARY & LSUR & LZETP & LZSN & NSUR & RETSC & SLSUR & UZSN \\
\hline \multicolumn{17}{|c|}{ Salado Creek Basin } \\
\hline \multicolumn{17}{|l|}{ PERLND } \\
\hline Undeveloped, A & 0 & 0.90 & 0 & 0.50 & 0.10 & 0.50 & 0.30 & 0.30 & 0 & 800 & 0.40 & 2.5 & 0.25 & -- & $0.10-0.04$ & 0.70 \\
\hline Undeveloped, B & 0 & .40 & 0 & .40 & .90 & .60 & .10 & .10 & 0 & 800 & .30 & 2.5 & .25 & -- & $.10-.04$ & .70 \\
\hline Undeveloped, C & 0 & .90 & 0 & .30 & .70 & .75 & .20 & .50 & 0 & 800 & .40 & 3.0 & .25 & -- & $.08-.03$ & .80 \\
\hline Undeveloped, D & -- & -- & -- & -- & -- & -- & -- & -- & -- & -- & -- & -- & -- & -- & -- & -- \\
\hline Residential, A & 0 & .90 & 0 & .50 & .10 & .50 & .30 & .30 & 0 & 800 & .40 & 2.5 & .25 & -- & $.10-.04$ & .70 \\
\hline Residential, B & 0 & .40 & 0 & .40 & .90 & .60 & .10 & .10 & 0 & 800 & .30 & 2.5 & .25 & -- & $.10-.04$ & .70 \\
\hline Residential, C & 0 & .90 & 0 & .30 & .70 & .75 & .20 & .50 & 0 & 800 & .40 & 3.0 & .25 & -- & $.08-.03$ & .80 \\
\hline Residential, D & -- & -- & -- & -- & -- & -- & -- & -- & -- & -- & -- & -- & -- & -- & -- & -- \\
\hline Commercial, A & 0 & .90 & 0 & .50 & .10 & .50 & .30 & .30 & 0 & 800 & .40 & 2.5 & .25 & -- & $.10-.04$ & .70 \\
\hline Commercial, B & 0 & .40 & 0 & .40 & .90 & .60 & .10 & .10 & 0 & 800 & .30 & 2.5 & .25 & -- & $.10-.04$ & .70 \\
\hline Commercial, C & 0 & .90 & 0 & .30 & .70 & .75 & .20 & .50 & 0 & 800 & .40 & 3.0 & .25 & -- & $.08-.03$ & .80 \\
\hline Commercial, D & -- & -- & -- & -- & -- & -- & -- & -- & -- & -- & -- & -- & -- & -- & -- & -- \\
\hline Transportation, A & 0 & .90 & 0 & .50 & .10 & .50 & .30 & .30 & 0 & 800 & .40 & 2.5 & .25 & -- & $.10-.04$ & .70 \\
\hline Transportation, B & 0 & .40 & 0 & .40 & .90 & .60 & .10 & .10 & 0 & 800 & .30 & 2.5 & .25 & -- & $.10-.04$ & .70 \\
\hline Transportation, C & 0 & .90 & 0 & .30 & .70 & .75 & .20 & .50 & 0 & 800 & .40 & 3.0 & .25 & -- & $.08-.03$ & .80 \\
\hline Transportation, D & -- & -- & -- & -- & -- & -- & -- & -- & -- & -- & -- & -- & -- & -- & -- & -- \\
\hline Industrial, A & 0 & .90 & 0 & .50 & .10 & .50 & .30 & .30 & 0 & 800 & .40 & 2.5 & .25 & -- & $.10-.04$ & .70 \\
\hline Industrial, B & 0 & .40 & 0 & .40 & .90 & .60 & .10 & .10 & 0 & 800 & .30 & 2.5 & .25 & -- & $.10-.04$ & .70 \\
\hline Industrial, C & 0 & .90 & 0 & .30 & .70 & .75 & .20 & .50 & 0 & 800 & .40 & 3.0 & .25 & -- & $.08-.03$ & .80 \\
\hline Industrial, D & -- & -- & -- & -- & -- & -- & -- & -- & -- & -- & -- & -- & -- & -- & -- & -- \\
\hline Services, A & 0 & .90 & 0 & .50 & .10 & .50 & .30 & .30 & 0 & 800 & .40 & 2.5 & .25 & -- & $.10-.04$ & .70 \\
\hline Services, B & 0 & .40 & 0 & .40 & .90 & .60 & .10 & .10 & 0 & 800 & .30 & 2.5 & .25 & -- & $.10-.04$ & .70 \\
\hline Services, C & 0 & .90 & 0 & .30 & .70 & .75 & .20 & .50 & 0 & 800 & .40 & 3.0 & .25 & -- & $.08-.03$ & .80 \\
\hline Services, D & -- & -- & -- & -- & -- & -- & -- & -- & -- & -- & -- & -- & -- & -- & -- & -- \\
\hline Quarries, A & 0 & .90 & 0 & .50 & .10 & .50 & .30 & .30 & 0 & 800 & .40 & 2.5 & .25 & -- & $.10-.04$ & .70 \\
\hline Quarries, B & 0 & .40 & 0 & .40 & .90 & .60 & .10 & .10 & 0 & 800 & .30 & 2.5 & .25 & -- & $.10-.04$ & .70 \\
\hline Quarries, C & 0 & .90 & 0 & .30 & .70 & .75 & .20 & .50 & 0 & 800 & .40 & 3.0 & .25 & -- & $.08-.03$ & .80 \\
\hline Quarries, D & -- & -- & -- & -- & -- & -- & -- & -- & -- & -- & -- & -- & -- & -- & -- & -- \\
\hline \multicolumn{17}{|l|}{ IMPLND } \\
\hline All categories & -- & -- & -- & -- & -- & -- & -- & -- & -- & 800 & -- & -- & .10 & .30 & $.10-.03$ & -- \\
\hline
\end{tabular}


$\vec{\infty} \quad$ Table 7. Selected annual PERLND and IMPLND process-related parameters for flow, San Antonio River watershed models, Bexar County, TexasContinued

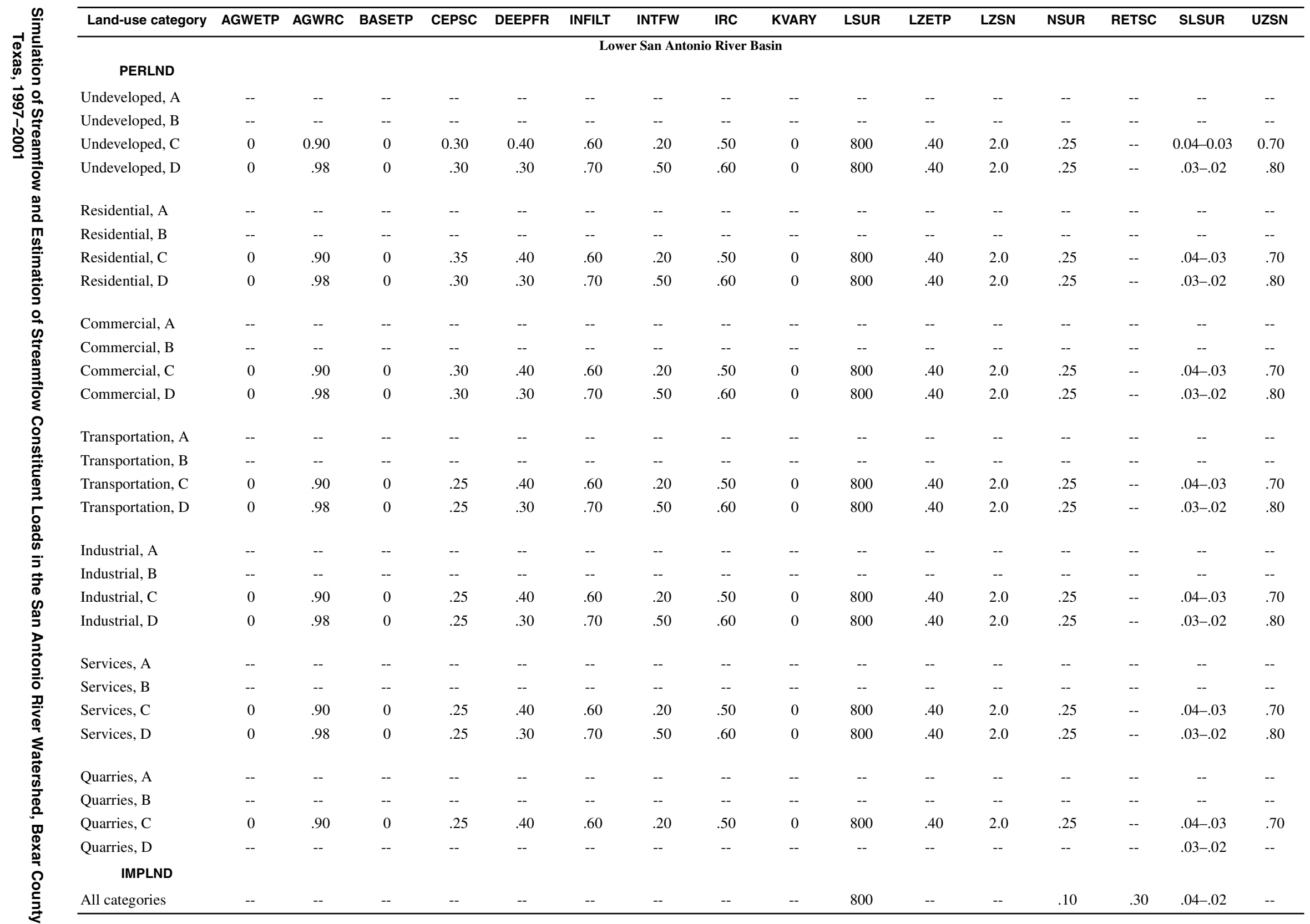


Table 8. Annual measured and simulated streamflow for basins in the San Antonio River watershed, Bexar County, Texas, 1997-2001

\begin{tabular}{|c|c|c|c|c|c|c|c|c|c|}
\hline \multirow[b]{2}{*}{ Period } & \multicolumn{3}{|c|}{ Lower Medina River Basin } & \multicolumn{3}{|c|}{ Leon Creek Basin } & \multicolumn{3}{|c|}{ Upper San Antonio River Basin } \\
\hline & $\begin{array}{c}\text { Measured } \\
\text { streamflow } \\
\text { (acre-feet) }\end{array}$ & $\begin{array}{c}\text { Simulated } \\
\text { streamflow } \\
\text { (acre-feet) }\end{array}$ & $\begin{array}{c}\text { Error } \\
\text { (percent) }\end{array}$ & $\begin{array}{c}\text { Measured } \\
\text { streamflow } \\
\text { (acre-feet) }\end{array}$ & $\begin{array}{l}\text { Simulated } \\
\text { streamflow } \\
\text { (acre-feet) }\end{array}$ & $\begin{array}{c}\text { Error } \\
\text { (percent) }\end{array}$ & $\begin{array}{c}\text { Measured } \\
\text { streamflow } \\
\text { (acre-feet) }\end{array}$ & $\begin{array}{l}\text { Simulated } \\
\text { streamflow } \\
\text { (acre-feet) }\end{array}$ & $\begin{array}{c}\text { Error } \\
\text { (percent) }\end{array}$ \\
\hline \multicolumn{10}{|l|}{ Calibration } \\
\hline 1997 & 266,000 & 270,000 & 1.5 & 33,400 & 30,500 & -8.7 & 52,200 & 64,800 & 24.1 \\
\hline 1998 & 311,000 & 326,000 & 4.8 & 73,400 & 62,900 & -14.2 & 75,300 & 90,000 & 19.5 \\
\hline 1999 & 125,000 & 104,000 & -16.8 & 10,200 & 10,100 & -.9 & 52,000 & 35,000 & -32.7 \\
\hline 2000 & 161,000 & 126,000 & -21.7 & 30,700 & 30,800 & .6 & 64,000 & 58,600 & -8.4 \\
\hline $1997-2000$ & 863,000 & 826,000 & -4.3 & 148,000 & 134,000 & -9.2 & 244,000 & 248,000 & 1.6 \\
\hline \multicolumn{10}{|l|}{ Testing } \\
\hline 2001 & 176,000 & 188,000 & 6.8 & 31,200 & 33,800 & 8.3 & 91,700 & 81,400 & -11.2 \\
\hline \multicolumn{10}{|l|}{ 1997-2001 } \\
\hline Total & $1,040,000$ & $1,010,000$ & -2.9 & 179,000 & 168,000 & -6.1 & 335,000 & 330,000 & -1.5 \\
\hline
\end{tabular}

\begin{tabular}{|c|c|c|c|c|c|c|}
\hline \multirow[b]{2}{*}{ Period } & \multicolumn{3}{|c|}{ Salado Creek Basin } & \multicolumn{3}{|c|}{ Lower San Antonio River Basin } \\
\hline & $\begin{array}{l}\text { Measured } \\
\text { streamflow } \\
\text { (acre-feet) }\end{array}$ & $\begin{array}{l}\text { Simulated } \\
\text { streamflow } \\
\text { (acre-feet) }\end{array}$ & $\begin{array}{c}\text { Error } \\
\text { (percent) }\end{array}$ & $\begin{array}{l}\text { Measured } \\
\text { streamflow } \\
\text { (acre-feet) }\end{array}$ & $\begin{array}{l}\text { Simulated } \\
\text { streamflow } \\
\text { (acre-feet) }\end{array}$ & $\begin{array}{c}\text { Error } \\
\text { (percent) }\end{array}$ \\
\hline \multicolumn{7}{|l|}{ Calibration } \\
\hline 1997 & 32,800 & 28,900 & -11.9 & 396,000 & 447,000 & 12.9 \\
\hline 1998 & 93,900 & 96,800 & 3.1 & 619,000 & 616,000 & .5 \\
\hline 1999 & 13,000 & 14,400 & 10.8 & 235,000 & 226,000 & -3.8 \\
\hline 2000 & 22,200 & 31,000 & 39.6 & 345,000 & 298,600 & -13.6 \\
\hline 1997-2000 & 162,000 & 171,000 & 5.5 & $1,595,000$ & $1,587,000$ & -.5 \\
\hline \multicolumn{7}{|l|}{ Testing } \\
\hline 2001 & 39,600 & 42,400 & 7.1 & 402,000 & 414,400 & 3.0 \\
\hline \multicolumn{7}{|l|}{ 1997-2001 } \\
\hline Total & 202,000 & 214,000 & 5.9 & $1,997,000$ & $2,000,000$ & .2 \\
\hline
\end{tabular}

2000 (a normal year) was within 1 percent of observed streamflow. The 2001 testing results oversimulated volume by 8.3 percent. Overall error for $1997-2001$ was -6.1 percent. A comparison of measured and simulated (7-day mean) streamflow at the Leon Creek station is shown in figure 7.

\section{Upper San Antonio River Basin}

The upper San Antonio River Basin and its subdivision into RCHRES segments are shown in figure 8. Two long-term USGS streamflow-gaging stations are used for model calibration. The upper $42.4 \mathrm{mi}^{2}$ of the basin, including most of downtown San Antonio, is gaged by the San Antonio River at Mitchell Street station (08178050). The lower station, San Antonio River at Loop 410 at San Antonio (08178565), gages the entire $125 \mathrm{mi}^{2}$ of the basin.

Overall error in simulated streamflow for the calibration period (1997-2000) was 1.6 percent (table 8); 1999 was substantially undersimulated (-32.7 percent error). The 2001 testing results undersimulated volume by 11.2 percent. Overall error 


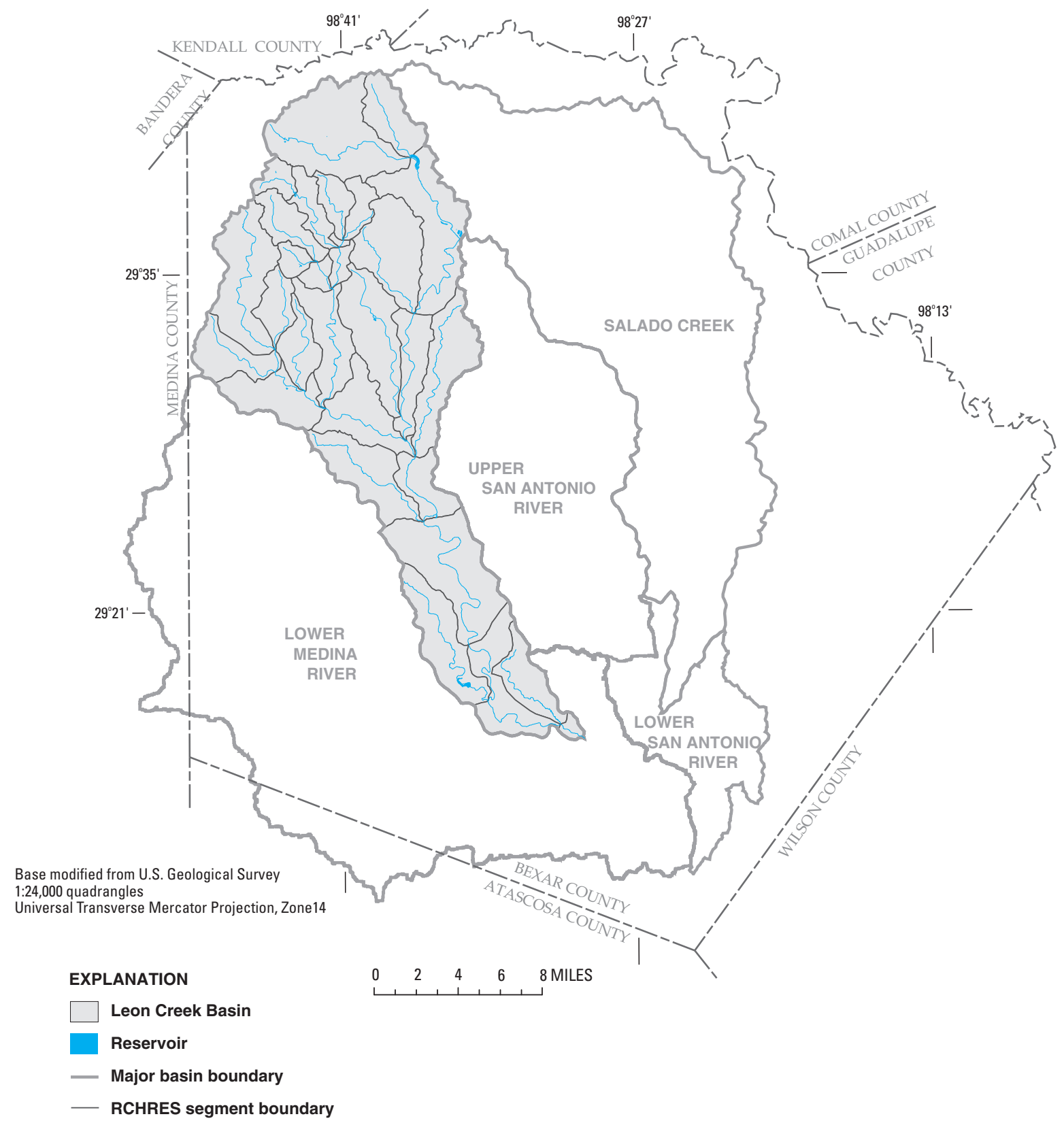

Figure 6. Leon Creek Basin stream and reservoir (RCHRES) segments.

for 1997-2001 was -1.5 percent. A comparison of measured and simulated (7-day mean) streamflow at the San Antonio River at Loop 410 station is shown in figure 9.

\section{Salado Creek Basin}

The Salado Creek Basin and its subdivision into RCHRES segments are shown in figure 10. Two long-term USGS streamflow-gaging stations were used for model calibration. The upper $125 \mathrm{mi}^{2}$ of the basin is gaged by the San Antonio River at Loop 410 (08178565). The lower station, Salado Creek at Loop 13 (08178800), gages $189 \mathrm{mi}^{2}$ of the entire $223-\mathrm{mi}^{2}$ basin. HSPF parameters obtained from the gaged part of the basin were applied to the ungaged part to estimate streamflow and constituent loads for the entire basin.

Overall error in simulated streamflow for the calibration period (1997-2000) was 5.5 percent (table 8); 2000 was substantially oversimulated (39.6 percent 

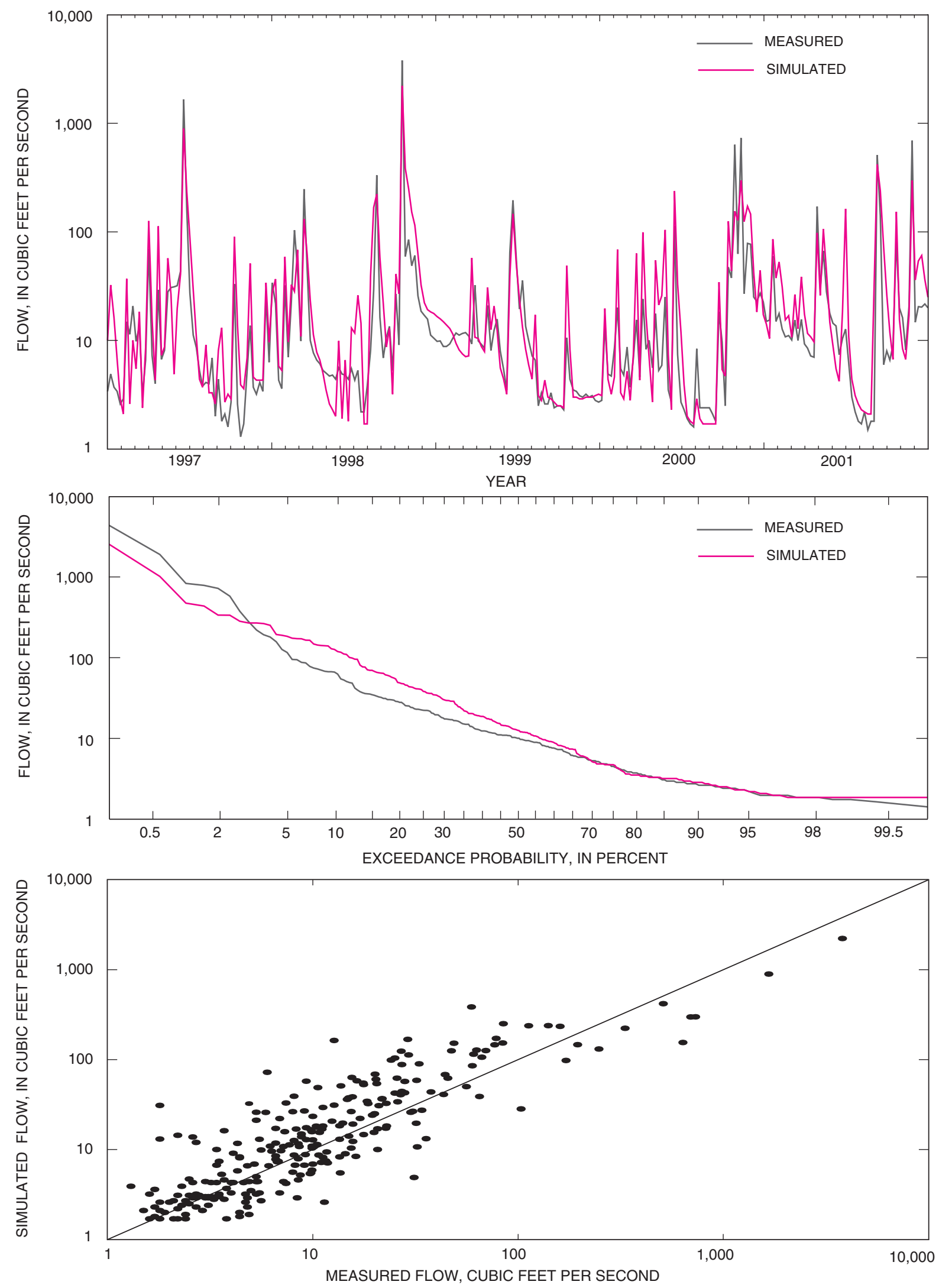

Figure 7. Measured and simulated 7-day mean streamflow at Leon Creek at $\mathrm{IH}-35$ at San Antonio, Texas (08181480), 1997-2001. 


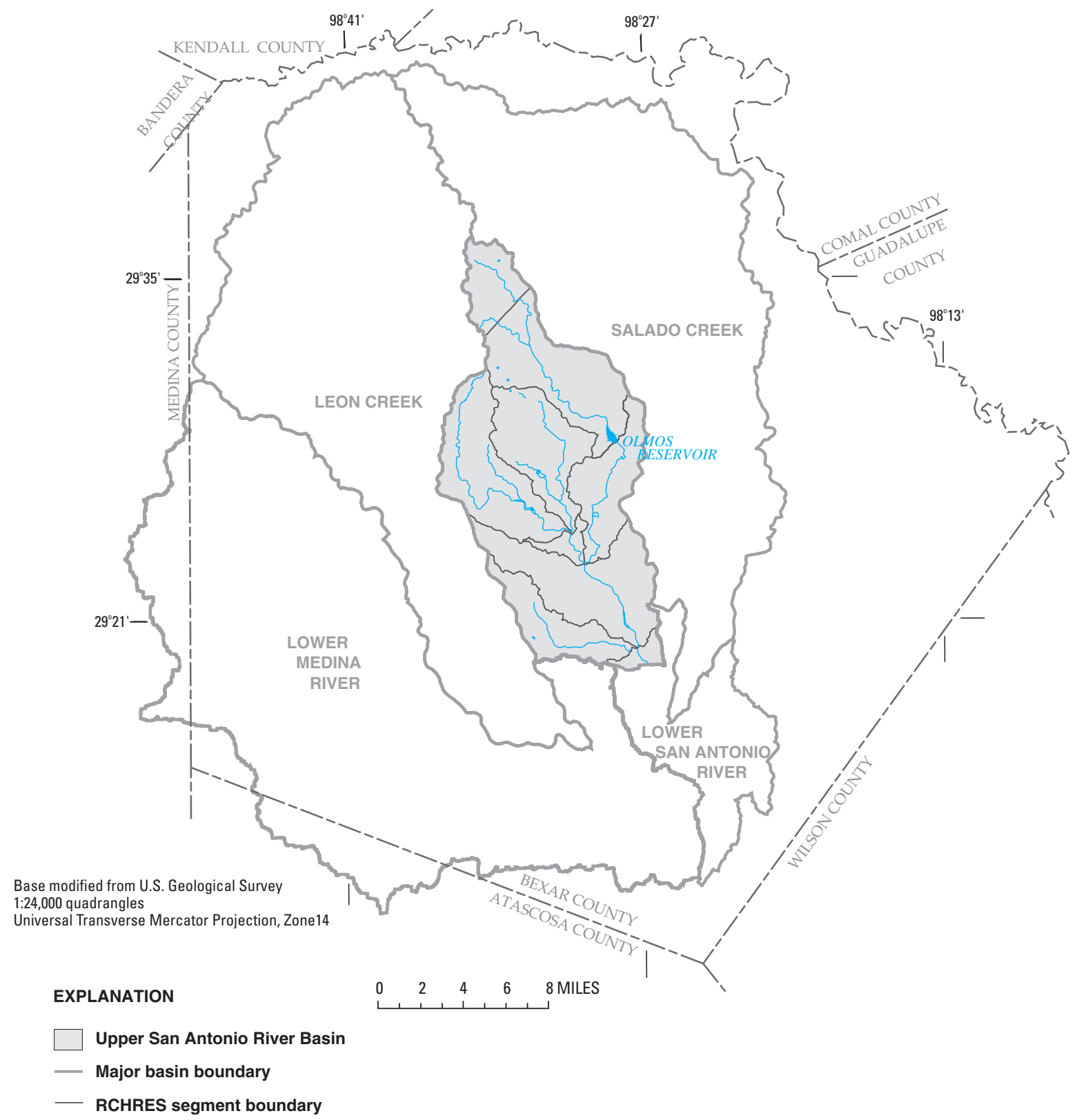

Figure 8. Upper San Antonio River Basin stream and reservoir (RCHRES) segments.

error). The 2001 testing results oversimulated volume by 7.1 percent. Overall error for 1997-2001 was 5.9 percent. A comparison of measured and simulated (7-day mean) streamflow at the Salado Creek at Loop 13 station is shown in figure 11 .

\section{Lower San Antonio River Basin}

The Lower San Antonio River Basin and its subdivision into RCHRES segments are shown in figure 12. The USGS streamflow-gaging station San Antonio
River near Elmendorf (08181800) was used for model calibration. Besides runoff from the basin, inflows from the four other basins, including recycled water discharges, enter this basin. Withdrawals from the San Antonio River are made to maintain normal levels in two power-generating plant reservoirs. These withdrawals mostly occur during dry summer months. Accuracy of simulated flow at the Elmendorf station depends largely on the accuracy of simulated flows from the contributing basins. 

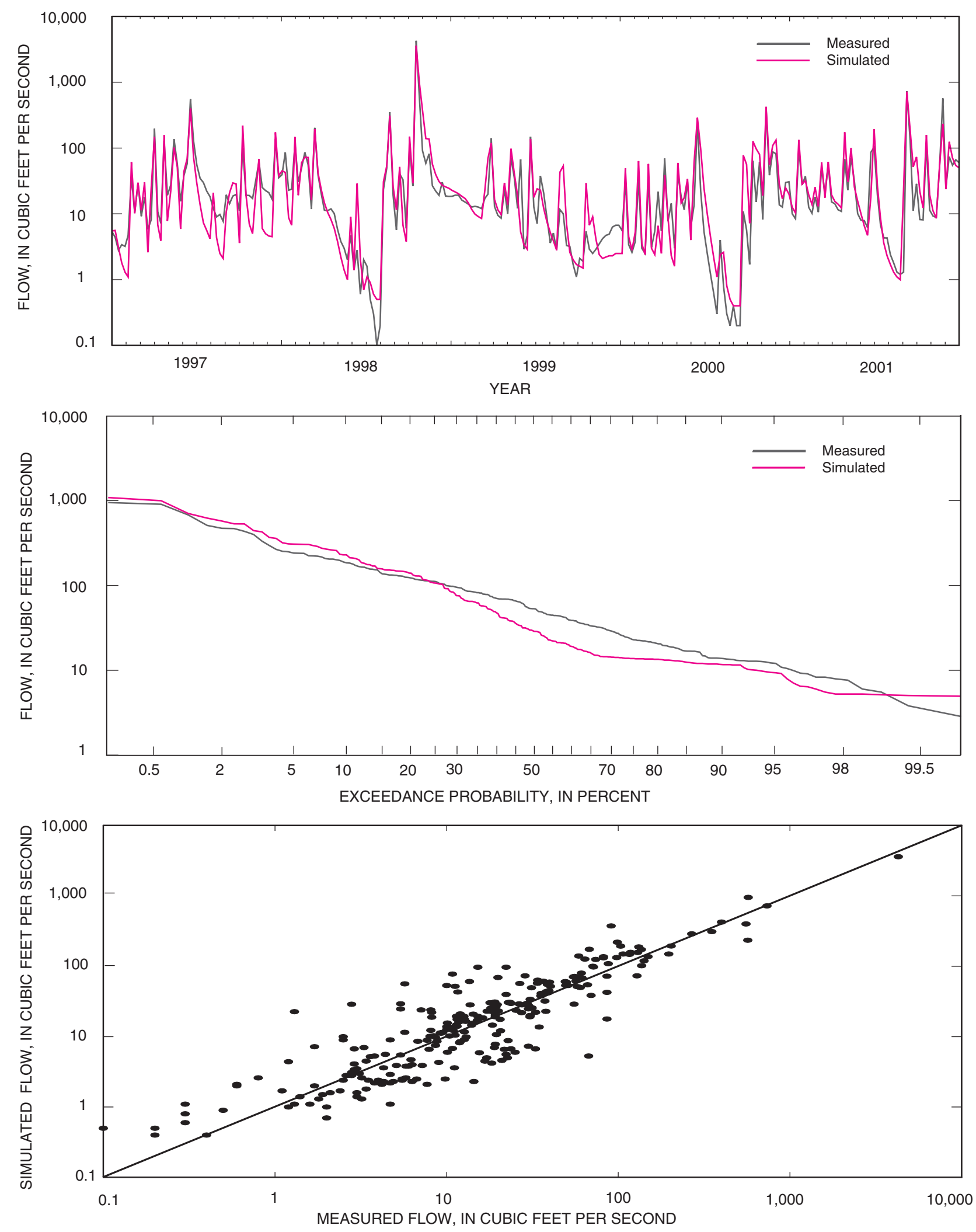

Figure 9. Measured and simulated 7-day mean streamflow at San Antonio River at Loop 410 at San Antonio, Texas (08178565), 1997-2001. 


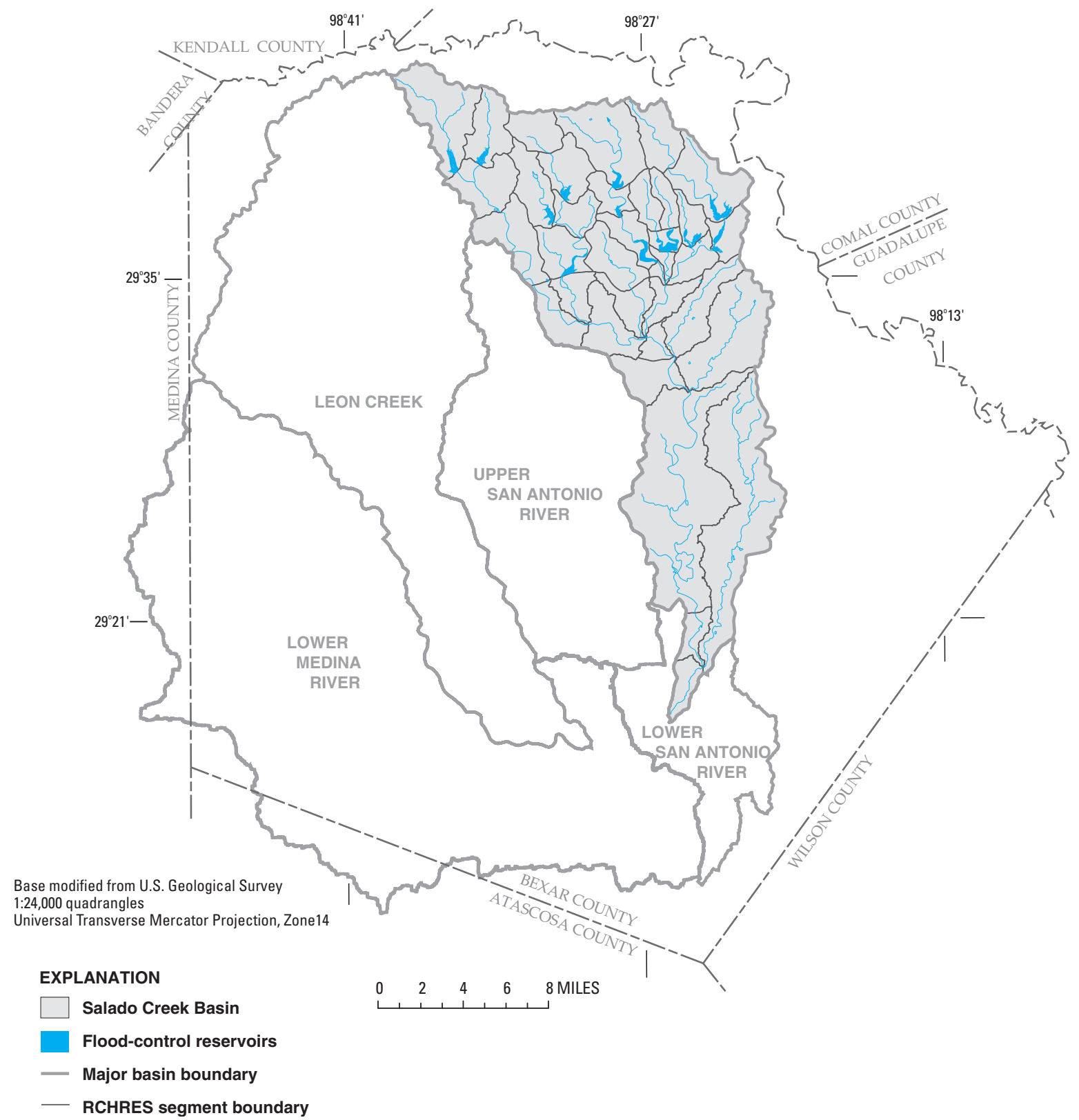

Figure 10. Salado Creek Basin stream and reservoir (RCHRES) segments.

The model calibration results of the lower San Antonio River Basin represent the integrated results of all study area models (table 8). Overall error in simulated streamflow for the calibration period (1997-2000) was -0.5 percent. The 2001 testing results oversimulated volume by 3.0 percent. Overall error for 1997-2001 was 0.2 percent. A comparison of measured and simulated (7-day mean) streamflow at the San Antonio River near Elmendorf station is shown in figure 13.

\section{Error Analysis}

The HSPF model provides reasonable simulations of runoff volumes compared with observed data. For each of the basins, total simulated volume for 1997-2001 was within 10 percent of measured runoff (table 8). At the basin outlet (San Antonio River near Elmendorf station), simulated volume was within 1 percent of measured volume. Annual errors in streamflow 

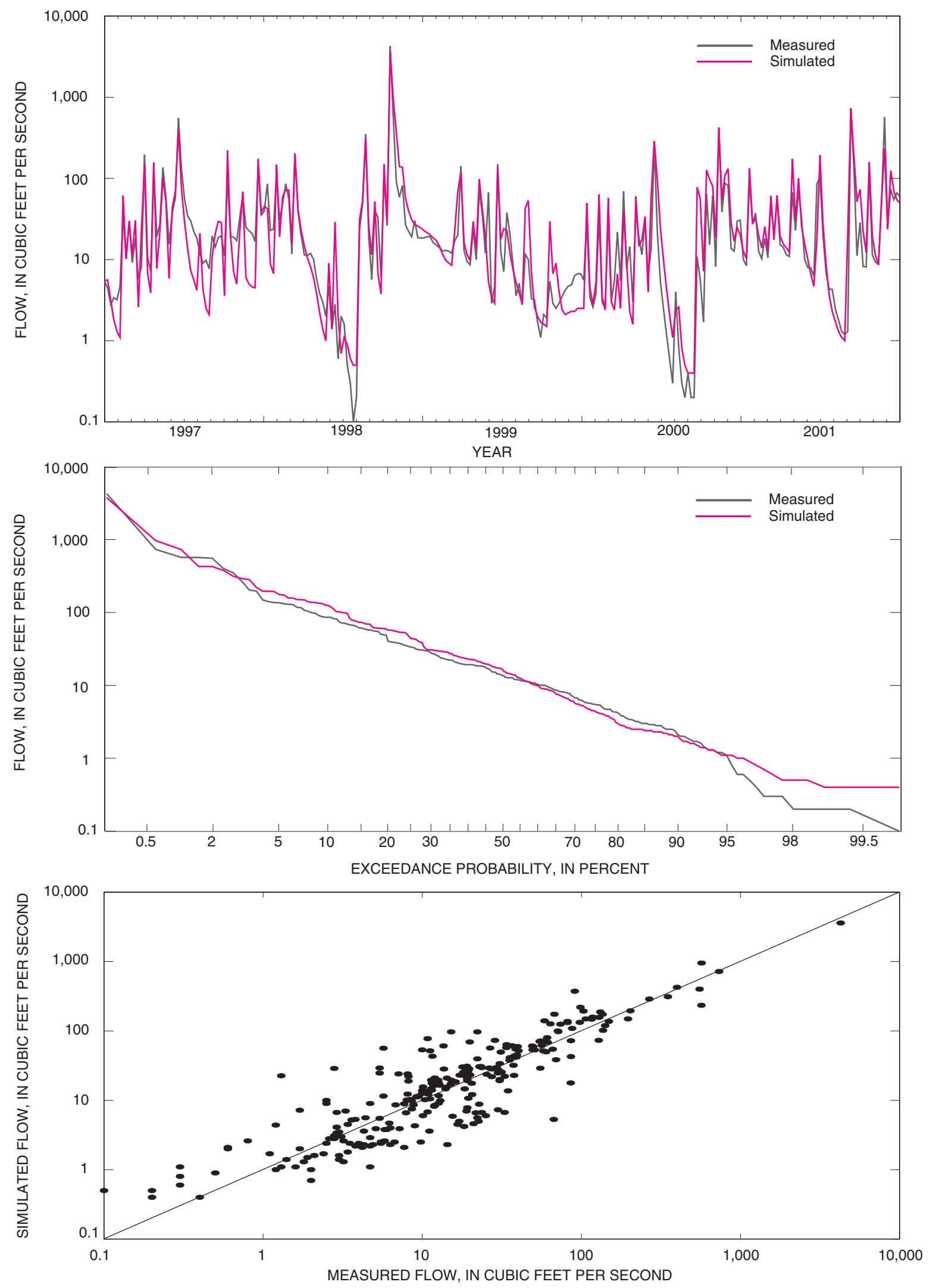

Figure 11. Measured and simulated 7-day mean streamflow at Salado Creek at Loop 13 at San Antonio, Texas (08178800), 1997-2001. 


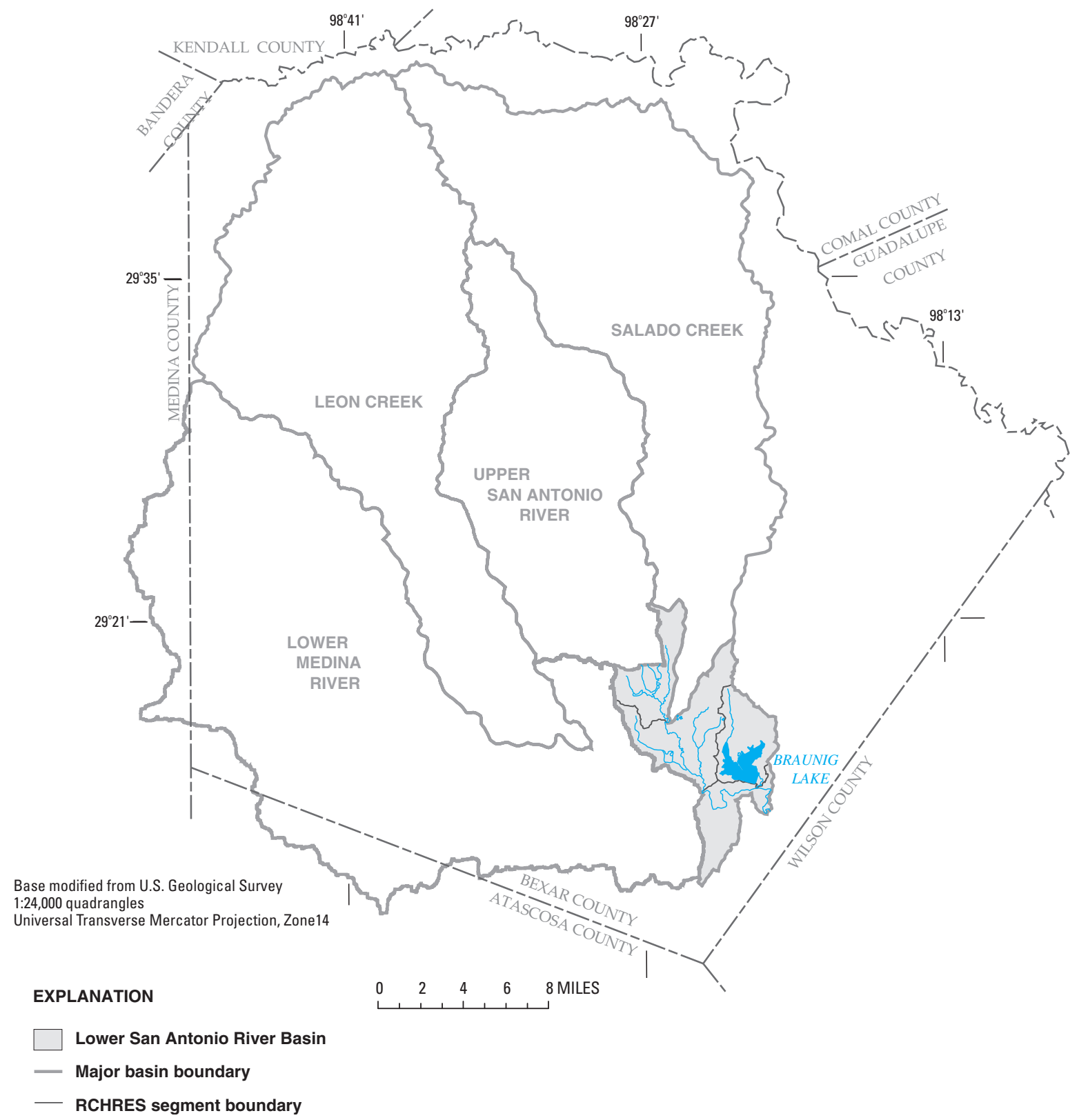

Figure 12. Lower San Antonio River Basin stream and reservoir (RCHRES) segments.

among the five basins ranged from -32.7 percent to 39.6 percent.

The types of error from model calibration and testing can be classified as measurement errors or systematic errors (Raines, 1996). Measurement errors are introduced as a result of missing data or inaccurate data used in the calibration or testing. For example, measured or gaged streamflow is subject to potential error in rating tables of stage and discharge. The spatial variability of rainfall in a watershed might not be adequately represented by the available network of rain gages.
Systematic errors are associated with limited ability of the simulation model to represent the hydrologic processes of the basins in the study area. Limits on how accurately the model parameters and equations describe the physical properties of runoff are possible. Also, the configuration of the model segments (PERLNDS, IMPLNDs, and RCHRESs) and selection of simulation time step (in this case, hourly) can only approximate the actual physical configuration and hydrologic responses of the basins. 

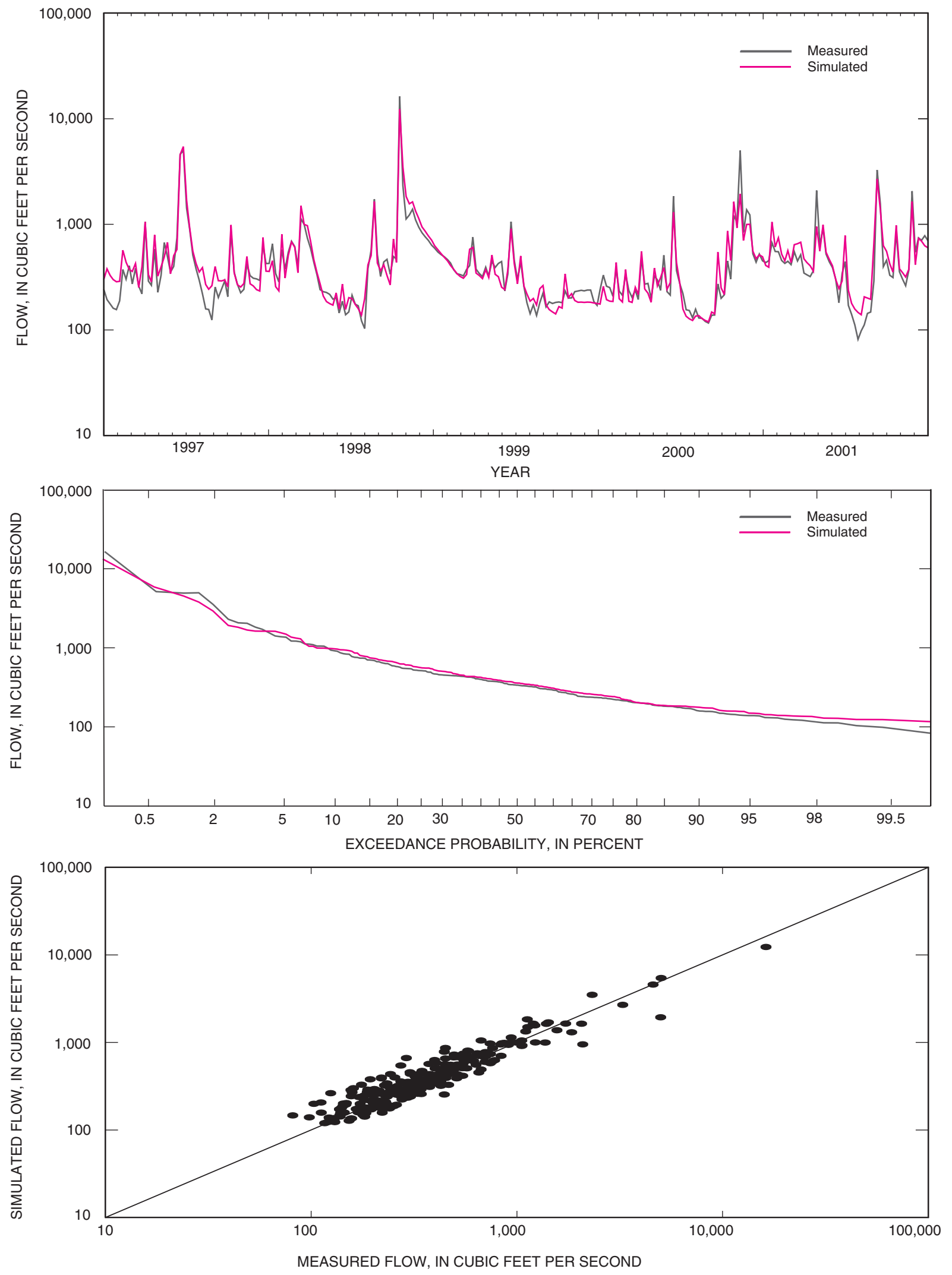

Figure 13. Measured and simulated 7-day mean streamflow at San Antonio River near Elmendorf, Texas (08181800), 1997-2001. 


\section{Sensitivity Analysis}

Because there is still some uncertainty in model parameter values after calibration and testing, sensitivity of selected HSPF process-related parameters was analyzed by altering values of selected parameters and evaluating the resulting changes in simulated streamflow.

The Salado Creek Basin was used to do a sensitivity analysis of selected HSPF model parameters to indicate what effect a change in a parameter value has on streamflow volumes. Each parameter was modified to represent a reasonable change. The resulting changes in streamflow at the lower gaging station in the basin (Salado Creek at Loop 13 at San Antonio) are shown in table 9.

The most sensitive parameters are lower-zone ET (LZETP) and lower-zone nominal storage (LZSN). A reduction in LZSN from 3.0 to 2.5 for all land uses in the $\mathrm{C}$ soils and geology grouping (Edwards aquifer confining unit-Blackland Prairie) resulted in a 2.4-percent increase in streamflow. Individually, none of the parameter changes caused relatively large changes to simulation results.

\section{Simulation of Streamflow by Basin and Source Category}

The 1997-2001 average annual contribution to streamflow at the San Antonio River near Elmendorf station, by basin, is shown in figure 14 . The lower
Medina River Basin, which includes inflow from the upper Medina River and discharge from the Medio Creek and Dos Rios WWRCs, is the largest contributor (31 percent). The lower San Antonio River Basin and Leon Creek Basin were the next largest contributors (23 and 19 percent, respectively). Both basins also include discharges from WWRCs. Sources of simulated streamflow for 1997-2001 at the outlet of the study area (San Antonio River near Elmendorf station) are shown in figure 15 and listed in table 10.

The average annual streamflow at the San Antonio River near Elmendorf station during 19972001 was 399,000 acre-feet (acre-ft). About 22 percent $(88,200$ acre-feet per year [acre-ft/yr] ) entered the study area as inflow from the upper Medina River, and about 20 percent $(79,800 \mathrm{acre}-\mathrm{ft} / \mathrm{yr})$ originated from recycled wastewater. Base flow accounted for about 18 percent $(72,600 \mathrm{acre}-\mathrm{ft} / \mathrm{yr})$ of the total streamflow. Surface runoff from various land uses provided about 33 percent $(132,000$ acre-ft/yr) of the total streamflow. Edwards aquifer springflow accounted for about 5 percent $(21,100 \mathrm{acre}-\mathrm{ft} / \mathrm{yr})$ of streamflow. Other sources of flow (primarily runoff from minor land uses) contributed about 1.4 percent $(5,600 \mathrm{acre}-\mathrm{ft} / \mathrm{yr})$ of the total streamflow.

\section{ESTIMATION OF STREAMFLOW CONSTITUENT LOADS}

In this report a constituent load is the mass of a constituent moved past a point by water in a specified

Table 9. Sensitivity of selected annual process-related parameters, Salado Creek Basin, 1997-2001

[Parameter definitions and units in table 5; B, Edwards aquifer outcrop; C, Edwards aquifer upper confining unit-Blackland Prairie]

Change $=100 *[(\mathrm{~A}-\mathrm{I}) / \mathrm{I}]$ where $\mathrm{A}=$ adjusted value; $\mathrm{I}=$ initial value $]$

\begin{tabular}{llcccc}
\hline Parameter & \multicolumn{1}{c}{$\begin{array}{c}\text { Land-use } \\
\text { category }\end{array}$} & $\begin{array}{c}\text { Initial } \\
\text { value }\end{array}$ & $\begin{array}{c}\text { Adjusted } \\
\text { value }\end{array}$ & $\begin{array}{c}\text { Change in parameter } \\
\text { (percent) }\end{array}$ & $\begin{array}{c}\text { Change in streamflow } \\
\text { (percent) }\end{array}$ \\
\hline CEPSC & Undeveloped, B & 0.40 & 0.30 & -25 & 0.30 \\
DEEPFR & All categories, B & .90 & .80 & -11 & 1.1 \\
INFILT & All categories, B & .60 & .70 & 17 & -.70 \\
INFILT & Residential, C & .75 & .85 & 13 & -.10 \\
INTFW & Undeveloped, C & .20 & .40 & 100 & -.10 \\
& & & & & \\
IRC & Undeveloped, C & .50 & .40 & -20 & 0 \\
LZETP & All categories, B & .30 & .25 & -17 & 1.2 \\
LZETP & All categories, C & .40 & .50 & 25 & -2.1 \\
LZSN & All categories, C & 3.0 & 2.5 & -17 & 2.4 \\
UZSN & All categories, C & .80 & .75 & -6.2 & .70 \\
\hline
\end{tabular}




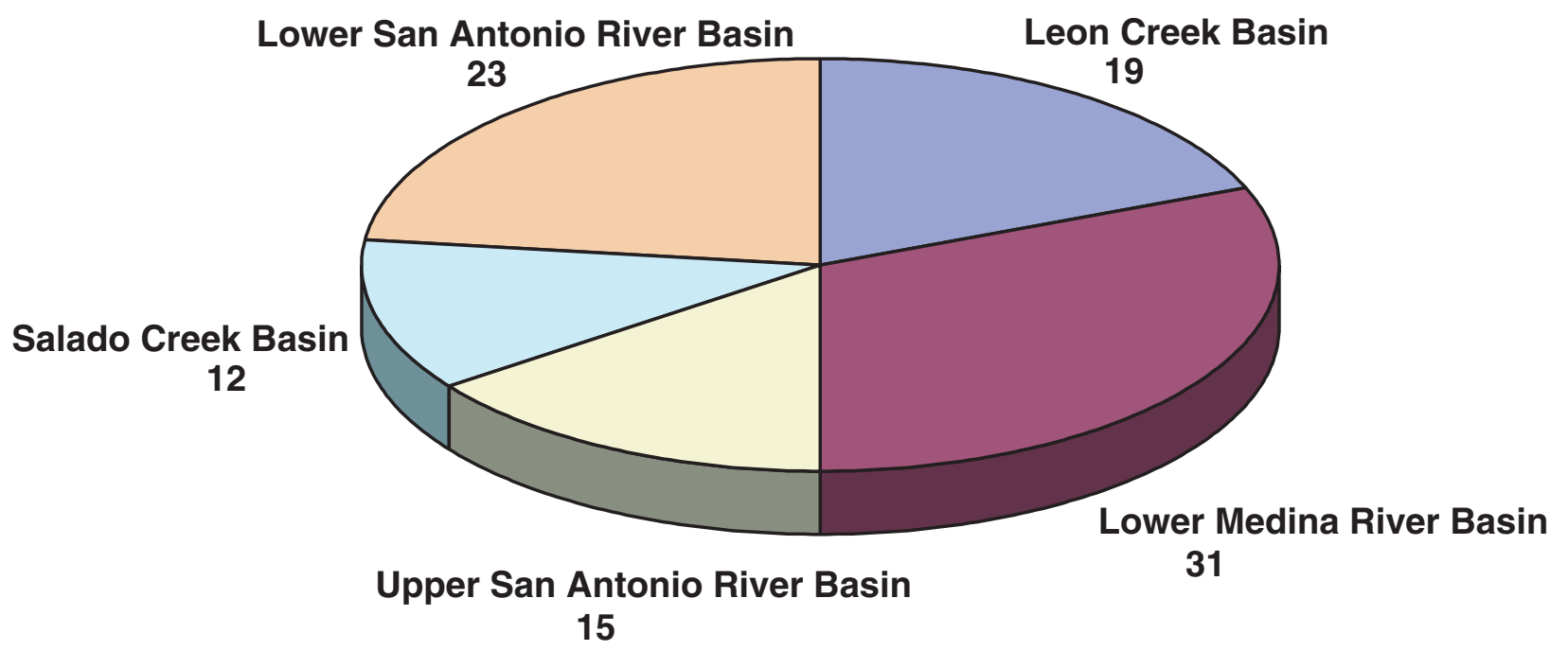

Average annual streamflow, 1997-2001,

San Antonio River near Elmendorf, Texas:

399,000 acre-feet per year

Figure 14. Contribution to streamflow, in percent, at San Antonio River at Elmendorf, Texas (08181800), 19972001.

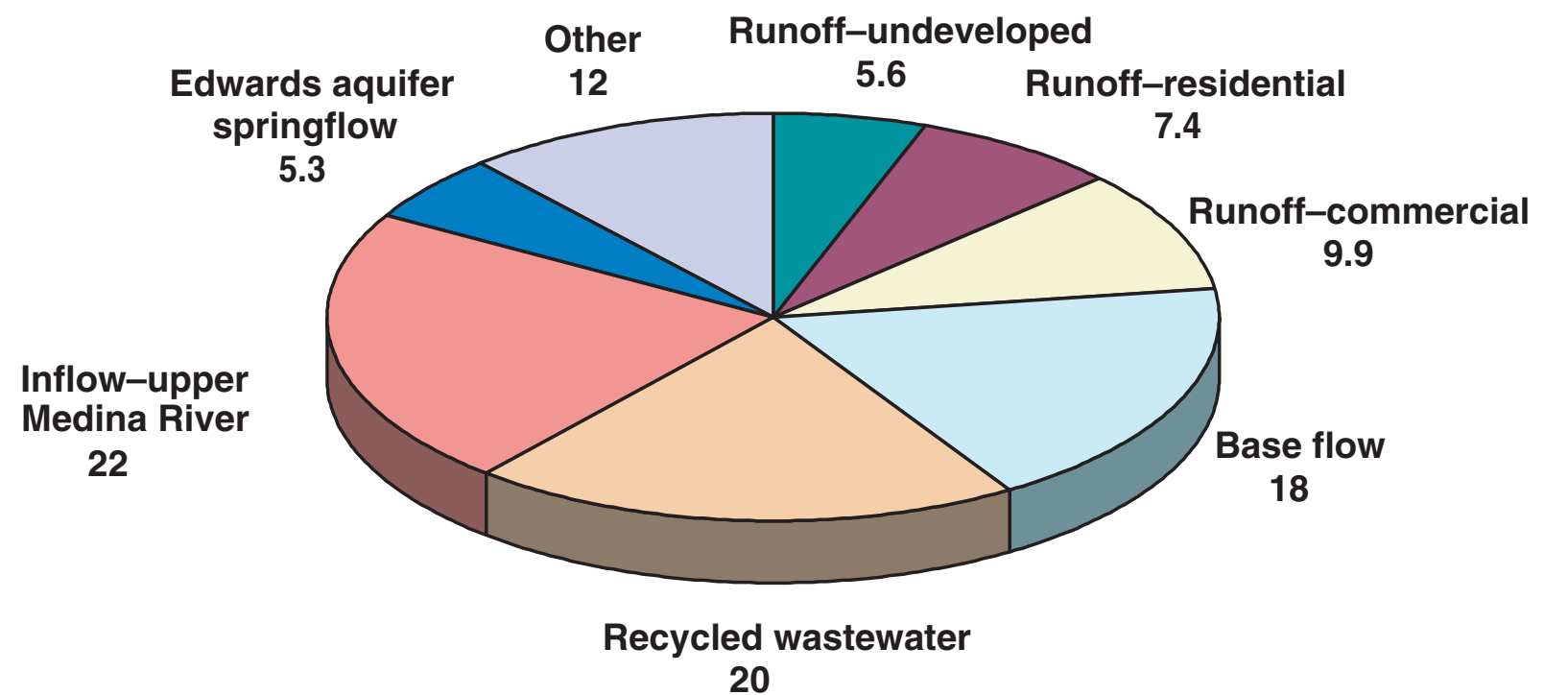

Figure 15. Sources of simulated streamflow, in percent, at San Antonio River near Elmendorf, Texas (08181800), 1997-2001.

time. Streamflow loads were estimated using average or median concentrations of dissolved solids, dissolved nitrate plus nitrite nitrogen, suspended solids, and total lead.

The HSPF models were configured by land-use and flow-source category so that the sources of stream- flow could be accounted for during the simulations. These sources include surface runoff from various landuse categories (undeveloped, residential, commercial, transportation, and industrial), stream base flow (originating as ground-water inflow to streams), recycled wastewater discharges, upper Medina River inflow from 
Table 10. Sources of simulated streamflow at San Antonio River near Elmendorf, Texas (08181800), 1997-2001

\begin{tabular}{lcccccc}
\hline \multirow{2}{*}{ Source } & \multicolumn{7}{c}{$\begin{array}{c}\text { Simulated streamflow } \\
\text { (percent of total flow }{ }^{1} \text { ) }\end{array}$} \\
\cline { 2 - 7 } & $\mathbf{1 9 9 7}$ & $\mathbf{1 9 9 8}$ & $\mathbf{1 9 9 9}$ & $\mathbf{2 0 0 0}$ & $\mathbf{2 0 0 1}$ & $\mathbf{1 9 9 7 - 2 0 0 1}$ \\
\hline Runoff-undeveloped & 3.1 & 14 & 0.10 & 1.4 & 3.3 & 5.6 \\
Runoff-residential & 6.5 & 8.3 & 4.2 & 9.1 & 7.6 & 7.4 \\
Runoff-commercial & 9.2 & 9.3 & 6.3 & 13 & 11 & 9.9 \\
Runoff-transportation corridor & 5.7 & 5.6 & 3.6 & 7.7 & 6.6 & 25.9 \\
Runoff-industrial & 2.2 & 2.3 & 1.6 & 2.9 & 2.4 & 22.3 \\
Runoff-services & 1.6 & 2.1 & 1.1 & 2.2 & 1.9 & 21.9 \\
Other (land use) & .80 & 1.9 & 1.7 & .90 & 1.3 & 21.4 \\
Base flow & 19 & 17 & 17 & 17 & 20 & 18 \\
Inflow-upper Medina River & 32 & 22 & 21 & 16 & 18 & 22 \\
Recycled wastewater & 18 & 13 & 34 & 26 & 20 & 20 \\
Edwards aquifer springflow & 2.0 & 4.7 & 10 & 3.8 & 8.0 & 5.3 \\
\hline
\end{tabular}

${ }^{1}$ Might not total 100 percent because of rounding.

${ }^{2}$ Grouped as other in figure 15 .

outside the study area, and springflow originating from Edwards aquifer springs. Average or median constituent concentrations were determined (using available waterquality data) to characterize water quality from each of these various flow sources. Then constituent loads originating from each source were computed using the equation

$$
\mathrm{L}_{\mathrm{s}}=\mathrm{R}_{\mathrm{s}} \times \mathrm{C}_{\mathrm{s}} \times \mathrm{cf},
$$

where

$\mathrm{L}_{\mathrm{S}}=$ constituent load from a particular source of flow (for example, residential runoff or recycled wastewater), in pounds;

$\mathrm{R}_{\mathrm{S}}=$ HSPF-simulated runoff volume from a particular source of flow, in acre-feet;

$\mathrm{C}_{\mathrm{S}}=$ source concentration-average or median concentration characteristic of flow from a particular source, in milligrams per liter or micrograms per liter; and

$\mathrm{cf}=$ conversion factor, 2.718 for concentrations in milligrams per liter or 0.00272 for concentrations in micrograms per liter.

Constituent loads from each source were summed to estimate overall streamflow constituent loads at the study area outlet.

\section{Source Concentrations Used for San Antonio River Constituent Loads Estimation}

Available water-quality data include stormwater runoff samples, base-flow samples, streamflow samples representative of the upper Medina River, recycled wastewater effluent samples, and ground-water samples from Edwards aquifer wells. Data-collection sites (excluding wells and sites outside the study area) are shown in figure 2 and listed in table 2.

An event-mean concentration (EMC) represents a discharge-weighted average constituent concentration during storm runoff (Charbeneau and Barrett, 1998). Two sources of Bexar County EMC data were available to characterize stormwater runoff quality for this study. EMC data collected during 1997-2000 for undeveloped, residential, and commercial land uses are available from a water-quality study of basins in the Edwards aquifer outcrop and catchment area in Bexar County (Ockerman, 2002). EMC data for residential, commercial, transportation, and industrial land use were obtained from a study done by the USGS and SAWS for the San Antonio NPDES program (B.L. Petri, U.S. Geological Survey, written commun., 2002). Only one industrial basin and one transportation corridor basin were sampled in the study. Because of the small number of sites to characterize water quality for these land uses, data from an NPDES characterization study done in the 
Table 11. Water-quality concentrations used for estimation of streamflow constituent loads [mg/L, milligrams per liter; $\mu \mathrm{g} / \mathrm{L}$, micrograms per liter]

\begin{tabular}{|c|c|c|c|c|c|c|}
\hline \multirow[b]{2}{*}{ Constituent } & \multicolumn{6}{|c|}{ Average concentration, stormwater runoff } \\
\hline & Undeveloped & Residential & Commercial & $\begin{array}{l}\text { Transportation } \\
\text { corridor }\end{array}$ & Industrial & $\begin{array}{c}\text { Other } \\
\text { (land use) }\end{array}$ \\
\hline Dissolved solids (mg/L) & 124 & 71 & 65 & 152 & 76 & 98 \\
\hline Nitrate plus nitrite nitrogen (mg/L) & .51 & .54 & .55 & .55 & .60 & .55 \\
\hline Suspended solids (mg/L) & 172 & 140 & 204 & 159 & 192 & 173 \\
\hline Total lead $(\mu \mathrm{g} / \mathrm{L})$ & 8 & 37 & 65 & 21 & 39 & 34 \\
\hline
\end{tabular}

\begin{tabular}{lcccc}
\hline \multicolumn{1}{c}{ Constituent } & $\begin{array}{c}\text { Median } \\
\text { concentration, } \\
\text { base flow }\end{array}$ & $\begin{array}{c}\text { Average } \\
\text { concentration, } \\
\text { inflow-upper } \\
\text { Medina River }\end{array}$ & $\begin{array}{c}\text { Median } \\
\text { concentration, } \\
\text { recycled } \\
\text { wastewater }\end{array}$ & $\begin{array}{c}\text { Average } \\
\text { concentration, } \\
\text { Edwards aquifer } \\
\text { springflow }\end{array}$ \\
\hline Dissolved solids $(\mathrm{mg} / \mathrm{L})$ & 400 & 350 & 609 & 327 \\
Nitrate plus nitrite nitrogen $(\mathrm{mg} / \mathrm{L})$ & 1.5 & 4.22 & 15 & 1.84 \\
Suspended solids $(\mathrm{mg} / \mathrm{L})$ & 10 & 129 & 3 & 1 \\
Total lead $(\mu \mathrm{g} / \mathrm{L})$ & .5 & .5 & .5 & 0 \\
\hline
\end{tabular}

Dallas-Fort Worth metropolitan area also were used (Baldys and others, 1997). The Dallas-Fort Worth study included eight industrial sites and four transportation corridor sites. Combined, the data from the three studies represent about 275 storm samples collected among five land-use categories and 26 sites. The data were grouped by land use, and average runoff concentrations were computed (table 11).

Base flow is defined as shallow ground-water contributions to streamflow. Water-quality concentrations were obtained from 133 base-flow (low flow, assumed to consist primarily of base flow) samples collected at USGS streamflow-gaging stations Leon Creek at IH-35 at San Antonio (08181480), San Antonio River at Loop 410 at San Antonio (08178565), and Salado Creek at Loop 13 at San Antonio (08178800) (table 2). Base-flow samples at these stations were collected upstream of wastewater discharges. Median concentrations used for estimation of constituent loads are listed in table 11.

Quality of flow entering the study area from the upper Medina River was characterized from 31 samples collected at USGS streamflow-gaging stations Medina River at La Coste (08180640) and Medina River near Macdona (08180700) during 1997-2000. Average constituent concentrations are listed in table 11.
Recycled wastewater quality was obtained from 131 effluent samples collected from the four major WWRCs and analyzed by the USGS during 1992-95. Median constituent concentrations are listed in table 11.

Water quality of Edwards aquifer springflow was characterized from 50 ground-water samples collected from 30 Bexar County Edwards aquifer wells during 1998-2002 (C.L. Otero, U.S. Geological Survey, written commun., 2002). Sample analyses included dissolved solids and nitrate plus nitrite nitrogen but did not include suspended solids and total lead. However, unfiltered turbidity and dissolved lead were measured and used to estimate suspended solids and total lead, respectively. Average constituent concentrations are listed in table 11 .

Some runoff occurs from minor land-use categories for which concentration data are not available. Services, quarries, and some military land use are primary examples of this type of land use. Constituent concentrations used to estimate runoff loads originating from these land uses were computed as the average of the other five land-use concentrations and are listed in table 11 under "other." 

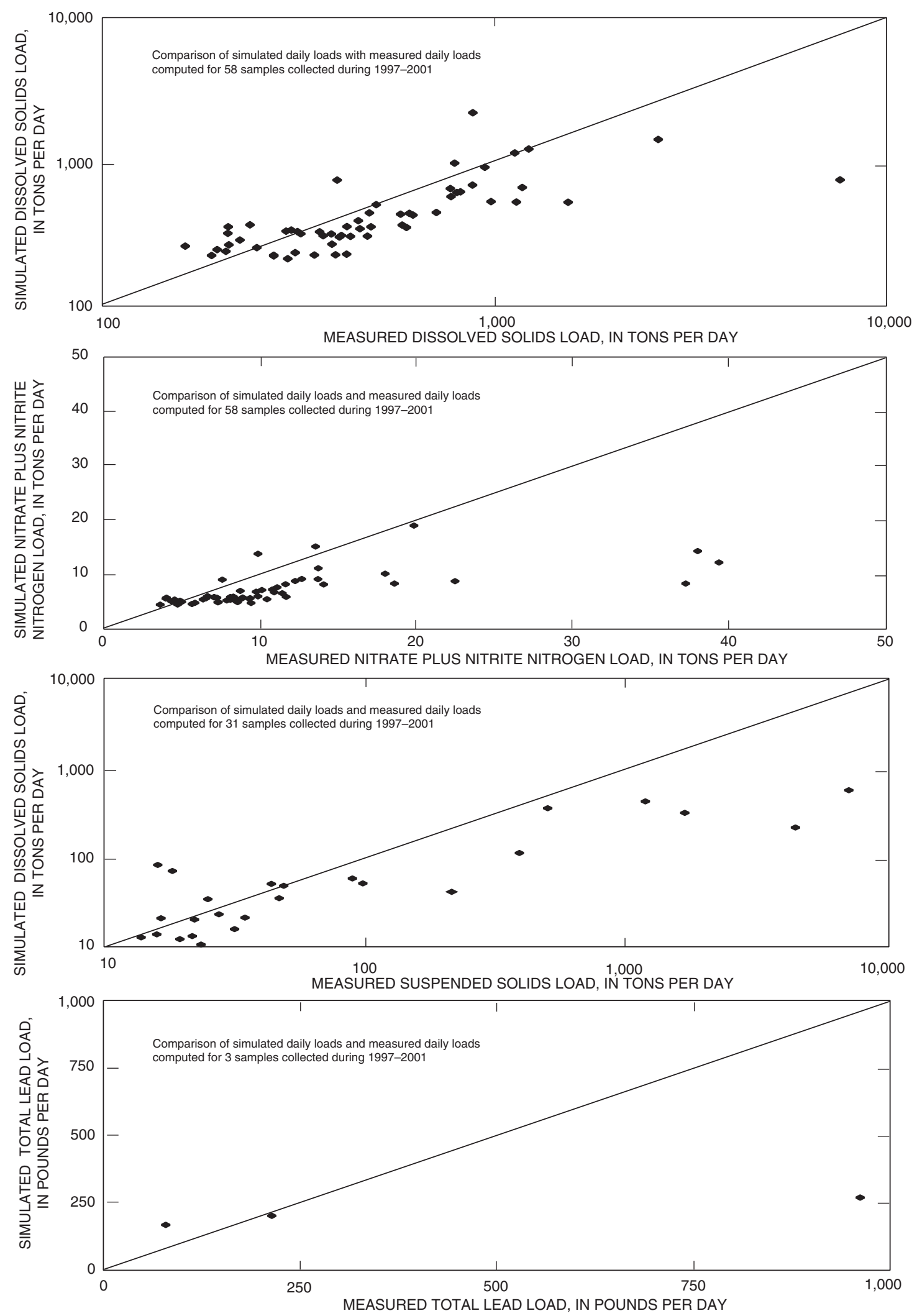

Figure 16. Comparison of streamflow loads estimated from Hydrological Simulation Program-FORTRANsimulated flow and source concentrations with loads computed from actual samples at San Antonio River near Elmendorf, Texas (08181800), 1997-2001. 


\section{Dissolved solids}

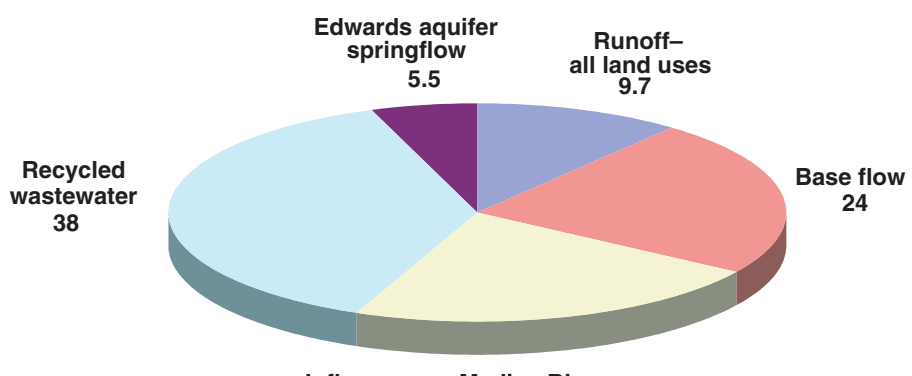

Inflow-upper Medina River

22

\section{Suspended solids}

\section{Nitrate plus nitrite nitrogen}
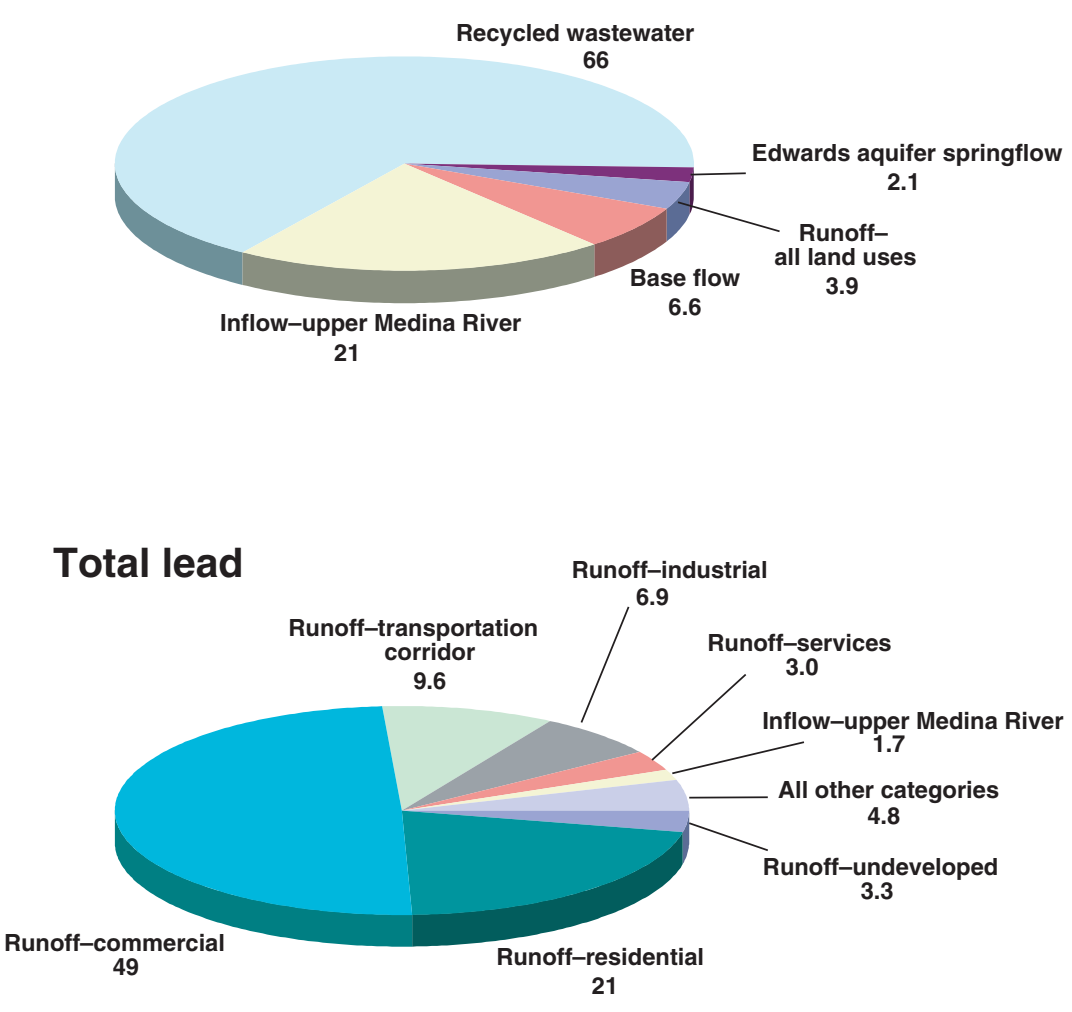

Figure 17. Sources of selected streamflow constituent loads, in percent, San Antonio River near Elmendorf, Texas (08181800), $1997-2001$. 
Table 12. Estimates of selected annual streamflow constituent loads, by source, San Antonio River watershed, Bexar County, Texas, 1997-2001

\begin{tabular}{|c|c|c|c|c|}
\hline Source & $\begin{array}{l}\text { Dissolved solids } \\
\text { (tons) }\end{array}$ & $\begin{array}{l}\text { Nitrate plus } \\
\text { nitrite nitrogen } \\
\text { (tons) }\end{array}$ & $\begin{array}{l}\text { Suspended solids } \\
\text { (tons) }\end{array}$ & $\begin{array}{l}\text { Total lead } \\
\text { (pounds) }\end{array}$ \\
\hline \multicolumn{5}{|l|}{1997} \\
\hline Runoff-undeveloped & 2,400 & 10.0 & 3,330 & 310 \\
\hline Runoff-residential & 2,880 & 22.0 & 5,670 & 2,990 \\
\hline Runoff-commercial & 3,700 & 31.0 & 11,600 & 7,410 \\
\hline Runoff-transportation corridor & 5,370 & 19.0 & 5,610 & 1,490 \\
\hline Runoff-industrial & 1,050 & 8.00 & 2,660 & 1,080 \\
\hline Runoff-services & 700 & 5.00 & 1,390 & 420 \\
\hline Other (land use) & 470 & 3.00 & 80.0 & 320 \\
\hline Base flow & 46,400 & 230 & 1,160 & 120 \\
\hline Inflow-upper Medina River & 62,200 & 840 & 56,200 & 400 \\
\hline Recycled wastewater & 67,600 & 1,690 & 340 & 110 \\
\hline Edwards aquifer springflow & 4,030 & 23.0 & 12.0 & 0 \\
\hline Total & 197,000 & 2,880 & 88,100 & 14,600 \\
\hline Source & $\begin{array}{l}\text { Dissolved solids } \\
\text { (tons) }\end{array}$ & $\begin{array}{l}\text { Nitrate plus } \\
\text { nitrite nitrogen } \\
\text { (tons) }\end{array}$ & $\begin{array}{l}\text { Suspended solids } \\
\text { (tons) }\end{array}$ & $\begin{array}{l}\text { Total lead } \\
\text { (pounds) }\end{array}$ \\
\hline \multicolumn{5}{|l|}{1998} \\
\hline Runoff-undeveloped & 15,140 & 62.0 & 21,000 & 1,950 \\
\hline Runoff-residential & 5,080 & 39.0 & 10,000 & 5,300 \\
\hline Runoff-commercial & 5,220 & 44.0 & 16,400 & 10,400 \\
\hline Runoff-transportation corridor & 7,310 & 26.0 & 7,640 & 2,020 \\
\hline Runoff-industrial & 1,480 & 12.0 & 3,730 & 1,520 \\
\hline Runoff-services & 1,280 & 10.0 & 2,520 & 760 \\
\hline Other (land use) & 6,690 & 10.0 & 2,890 & 1,120 \\
\hline Base flow & 57,900 & 220 & 1,450 & 150 \\
\hline Inflow-upper Medina River & 58,700 & 790 & 23,800 & 370 \\
\hline Recycled wastewater & 68,600 & 1,720 & 340 & 110 \\
\hline Edwards aquifer springflow & 13,300 & 74.0 & 41.0 & 0 \\
\hline Total & 241,000 & 3,010 & 89,800 & 23,700 \\
\hline Source & $\begin{array}{l}\text { Dissolved solids } \\
\text { (tons) }\end{array}$ & $\begin{array}{l}\text { Nitrate plus } \\
\text { nitrite nitrogen } \\
\text { (tons) }\end{array}$ & $\begin{array}{l}\text { Suspended solids } \\
\text { (tons) }\end{array}$ & $\begin{array}{l}\text { Total lead } \\
\text { (pounds) }\end{array}$ \\
\hline \multicolumn{5}{|l|}{1999} \\
\hline Runoff-undeveloped & 24.0 & 0.100 & 33.0 & 3.00 \\
\hline Runoff-residential & 960 & 7.00 & 1,890 & 1,000 \\
\hline Runoff-commercial & 1,320 & 11.0 & 4,130 & 2,630 \\
\hline Runoff-transportation corridor & 1,770 & 6.00 & 1,850 & 490 \\
\hline Runoff-industrial & 390 & 3.00 & 970 & 400 \\
\hline Runoff-services & 240 & 2.00 & 480 & 140 \\
\hline Other (land use) & 560 & 4.00 & 970 & 200 \\
\hline Base flow & 21,600 & 81.0 & 540 & 27.0 \\
\hline Inflow-upper Medina River & 20,900 & 280 & 3,400 & 130 \\
\hline Recycled wastewater & 65,800 & 1,650 & 330 & 110 \\
\hline Edwards aquifer springflow & 10,800 & 60.0 & 33.0 & 0 \\
\hline Total & 124,000 & 2,100 & 14,600 & 5,130 \\
\hline
\end{tabular}


Table 12. Estimates of selected annual streamflow constituent loads, by source, San Antonio River watershed, Bexar County, Texas, 1997-2001-Continued

\begin{tabular}{|c|c|c|c|c|}
\hline Source & $\begin{array}{l}\text { Dissolved solids } \\
\text { (tons) }\end{array}$ & $\begin{array}{c}\text { Nitrate plus } \\
\text { nitrite nitrogen } \\
\text { (tons) }\end{array}$ & $\begin{array}{l}\text { Suspended solids } \\
\text { (tons) }\end{array}$ & $\begin{array}{l}\text { Total lead } \\
\text { (pounds) }\end{array}$ \\
\hline \multicolumn{5}{|l|}{2000} \\
\hline Runoff-undeveloped & 540 & 2.00 & 750 & 70.0 \\
\hline Runoff-residential & 2,730 & 21.0 & 5,390 & 2,850 \\
\hline Runoff-commercial & 3,610 & 31.0 & 11,300 & 7,220 \\
\hline Runoff-transportation corridor & 4,950 & 18.0 & 5,180 & 1,370 \\
\hline Runoff-industrial & 940 & 7.00 & 2,370 & 960 \\
\hline Runoff-services & 670 & 5.00 & 1,310 & 390 \\
\hline Other (land use) & 370 & 3.00 & 170 & 240 \\
\hline Base flow & 29,100 & 110 & 730 & 72.0 \\
\hline Inflow-upper Medina River & 21,200 & 290 & 9,900 & 135 \\
\hline Recycled wastewater & 65,600 & 1,640 & 330 & 110 \\
\hline Edwards aquifer springflow & 5,190 & 29.0 & 16.0 & 0 \\
\hline Total & 135,000 & 2,160 & 37,400 & 13,400 \\
\hline Source & $\begin{array}{l}\text { Dissolved solids } \\
\text { (tons) }\end{array}$ & $\begin{array}{c}\text { Nitrate plus } \\
\text { nitrite nitrogen } \\
\text { (tons) }\end{array}$ & $\begin{array}{l}\text { Suspended solids } \\
\text { (tons) }\end{array}$ & $\begin{array}{l}\text { Total lead } \\
\text { (pounds) }\end{array}$ \\
\hline \multicolumn{5}{|l|}{2001} \\
\hline Runoff-undeveloped & 590 & 2.00 & 820 & 77.0 \\
\hline Runoff-residential & 3,070 & 23.0 & 6,060 & 3,200 \\
\hline Runoff-commercial & 4,110 & 35.0 & 12,900 & 8,220 \\
\hline Runoff-transportation corridor & 5,740 & 21.0 & 6,000 & 1,590 \\
\hline Runoff-industrial & 1,040 & 8.00 & 2,640 & 1,070 \\
\hline Runoff-services & 790 & 6.00 & 1,570 & 470 \\
\hline Other (land use) & 740 & 4.00 & 1,290 & 510 \\
\hline Base flow & 52,900 & 198 & 1,320 & 130 \\
\hline Inflow-upper Medina River & 31,800 & 430 & 5,160 & 200 \\
\hline Recycled wastewater & 68,300 & 1,710 & 340 & 115 \\
\hline Edwards aquifer springflow & 15,100 & 84.0 & 46.0 & 0 \\
\hline Total & 184,000 & 2,520 & 38,100 & 15,600 \\
\hline
\end{tabular}

Table 13. Sources of selected streamflow constituent loads, San Antonio River near Elmendorf, Texas (08181800), 1997-2001

\begin{tabular}{|c|c|c|c|c|}
\hline Source & $\begin{array}{l}\text { Dissolved solids } \\
\text { (percent of total }{ }^{1} \text { ) }\end{array}$ & $\begin{array}{l}\text { Nitrate plus nitrite nitrogen } \\
\text { (percent of total }{ }^{1} \text { ) }\end{array}$ & $\begin{array}{l}\text { Suspended solids } \\
\text { (percent of total }{ }^{1} \text { ) }\end{array}$ & $\begin{array}{c}\text { Total lead } \\
\text { (percent of total }^{1} \text { ) }\end{array}$ \\
\hline Runoff-undeveloped & 2.1 & 0.60 & 9.8 & 3.3 \\
\hline Runoff-residential & 1.7 & .90 & 11 & 21 \\
\hline Runoff-commercial & 2.0 & 1.2 & 21 & 49 \\
\hline Runoff-transportation corridor & 2.9 & .70 & 9.9 & 9.6 \\
\hline Runoff-industrial & .60 & .30 & 4.7 & 6.9 \\
\hline Runoff-services & .40 & .20 & 2.7 & 3.0 \\
\hline Other (land use) & 1.0 & .30 & 1.2 & 3.3 \\
\hline Base flow & 24 & 6.6 & 2.0 & .70 \\
\hline Inflow-upper Medina River & 22 & 21 & 37 & 1.7 \\
\hline Recycled wastewater & 38 & 66 & .60 & .80 \\
\hline Edwards aquifer springflow & 5.5 & 2.1 & .10 & 0 \\
\hline
\end{tabular}

\footnotetext{
${ }^{1}$ Might not total 100 percent because of rounding.
} 


\section{Estimation of Streamflow Constituent Loads Using Source Concentrations With HSPF- Simulated Flow}

Source concentrations from table 11 were used with HSPF-simulated streamflow to estimate selected constituent loads at the San Antonio River near Elmendorf (08181800). To assess the reasonableness of the estimated loads and whether data used to characterize water quality from various sources are representative of overall streamflow loads in the study area, selected daily loads at the Elmendorf station were compared with loads computed by a different method. On the days during 1997-2001 when water-quality samples were collected at the Elmendorf station, selected daily constituent loads were computed using the "measured" (from water-quality sample) instream concentration and mean daily streamflow. This comparison of estimated and measured loads for dissolved solids, nitrate plus nitrite nitrogen, suspended solids, and total lead is shown in figure 16.

Loads estimated by the two methods are in relative agreement for smaller daily loads (which correspond to lower daily flows), especially for dissolved solids and nitrate plus nitrite nitrogen (both dissolved constituents). The HSPF source-concentration method underestimated loads for higher flows (compared with loads computed from actual samples and gaged mean daily flows), especially suspended solids and total lead. Also, only three samples were analyzed for total lead, and only one of those samples was at higher flow (fig. 16). Because loads were underestimated mostly for higher flows, water quality might not be adequately characterized for sources that contribute to higher flows such as stormwater runoff. Moreover, because suspended solids appear to be underestimated, other constituents that tend to be associated with sediment (metals, for example) might also be underestimated by the HSPF source-concentration method. Despite limitations at higher flows, the source-concentration method of estimating loads does provide a method to quantify loads from various land uses and sources.

Annual estimates of loads (HSPF sourceconcentration method) are listed by source in table 12; 1997-2001 constituent loads for each source as a percentage of total streamflow loads are listed in table 13. Sources of loads for dissolved solids, nitrate plus nitrite nitrogen, suspended solids, and total lead for 19972001 at the San Antonio River near Elmendorf station are shown in figure 17.
Sources of streamflow loads varied according to constituent. Recycled wastewater is the largest source of dissolved solids and nitrate plus nitrite nitrogen (about 38 and 66 percent, respectively). Inflow from the upper Medina River and base flow are the other major contributors of these constituents. Runoff from urban sources (all runoff except "runoff-undeveloped" in fig. 17) is the largest source of suspended solids loads (about 49 percent) and total lead loads (about 90 percent). Runoff from residential and commercial land, which represents about 23 percent of the land area, produced about 70 percent of the total lead streamflow load.

\section{SUMMARY}

The USGS developed HSPF watershed models to simulate runoff and streamflow constituent loads for the major basins of the San Antonio River watershed in Bexar County. A model parameter set for use with the HSPF model was developed from available data and used for model simulations to estimate streamflow and selected constituent loads. The San Antonio River Basin in Bexar County was divided into five major basins for the simulations. Each basin was further subdivided, resulting in a total of 103 stream or reservoir segments. Twenty-eight pervious land segments were defined for the study on the basis of four physiographic categories and seven land-use categories. To adequately represent the relatively rapid rainfall-runoff response of the study area basins, the model simulations were done using a 1hour time step. Streamflow and constituent loads were estimated for the period 1997-2001.

Model parameter calibration and simulations were done using data collected during 1997-2001 from six rain gages, 10 streamflow gages, and one evaporation station. The error in simulated runoff (difference between simulated and measured streamflow) at the study area outlet (USGS streamflow gaging station 08181800 San Antonio River near Elmendorf) for 1997-2001 was less than 1 percent. Annual error among the basins was greater, ranging from -32.7 to 39.6 percent.

The HSPF models were configured to assign runoff to various categories on the basis of land use or source of flow so that the sources, or components, of total streamflow at the study area outlet could be determined. During 1997-2001, about 22 percent of streamflow originated as inflow from the upper Medina River. Recycled wastewater accounted for about 20 percent of streamflow. Base flow (shallow ground water returning 
to streams) provided about 18 percent of total streamflow. Springflow, originating from Edwards aquifer springs, produced 5.3 percent of total streamflow. Storm runoff from various land uses represented about 33 percent of streamflow, mostly from commercial (9.9 percent) and residential (7.6 percent).

Streamflow constituent loads were computed by obtaining representative water-quality concentrations for each flow category or source, then applying the concentrations to the appropriate source category of HSPFsimulated flow volume. Data from more than 600 waterquality samples were analyzed to determine concentrations used to characterize the quality of streamflow originating from various sources. In addition, waterquality samples were collected at the study outlet (San Antonio River near Elmendorf station) so selected daily loads could be computed using the measured (sampled) concentration and the gaged streamflow. These measured loads were compared with loads estimated using HSPF-simulated streamflow and source concentrations. Overall, the HSPF source-concentration method underestimated loads (compared to loads computed from samples collected at the San Antonio River near Elmendorf station). Loads estimated using the two methods tended to agree more closely for the dissolved constituents (dissolved solids and nitrate plus nitrite nitrogen) than for constituents associated with suspended sediment (suspended solids and total lead). Also, loads estimated by both methods were in relatively good agreement for lower flows (smaller daily loads).

On the basis of the source-concentration estimates for 1997-2001, recycled wastewater is the largest source of dissolved solids and nitrate plus nitrite nitrogen streamflow loads (about 38 and 66 percent, respectively). Inflow from the upper Medina River and base flow also were major contributors to dissolved solids and nitrate plus nitrite nitrogen. In contrast, storm runoff was the primary source for suspended solids and total lead streamflow loads. Storm runoff from urban land accounted for about 49 percent of all suspended solids. Runoff from residential and commercial land (which represents about 23 percent of the land area) produced most of the total lead in streamflow (about 70 percent).

\section{REFERENCES}

Bicknell, B.R., Imhoff, J.C., Kittle, J.L. Jr., Donigian, A.S., Jr., and Johanson, R.C., 1997, Hydrological Simulation Program-FORTRAN, user's manual for version 11: Athens, Ga., U.S.Environmental Protection Agency, National Exposure Research Laboratory, EPA/600/R-97-080, 755 p.

Baldys, Stanley, III, Raines, T.H., Mansfield, B.L., and Sandlin, J.T., 1997, Hydrologic data for urban stormwater studies in the Dallas-Fort Worth area, Texas, 1992-94: U.S. Geological Survey Water-Resources Investigations Report 96-482, 256 p.

Brune, Gunnar, 1975, Major and historical springs of Texas: Texas Water Development Board Report 189, 94 p.

Bush, P.W., Ardis, A.F., Fahlquist, Lynne, Ging, P.B., Hornig, C.E., and Lanning-Rush, Jennifer, 2000, Water quality in south-central Texas, 1996-98: U.S. Geological Survey Circular 1212, 32 p.

Charbeneau, R.J., and Barrett, M.E., 1998, Evaluation of methods for estimating stormwater pollutant loads: Water Environment Research, v. 70, no. 7, p. 1,2951,302 .

Lumb, A.M., McCammon, R.B., and Kittle, J.L., 1994, Users manual for an expert system (HSPEXP) for calibration of the Hydrological Simulation Program-FORTRAN: U.S. Geological Survey Water-Resources Investigations Report 94-4168, 102 p.

Ockerman, D.J., 2002, Simulation of runoff and recharge and estimation of constituent loads in runoff, Edwards aquifer recharge zone (outcrop) and catchment area, Bexar County, Texas, 1997-2000: U.S. Geological Survey Water-Resources Investigations Report 02-4241, 31 p.

Ockerman, D.J., Petri, B.L., and Slattery, R.N., 1999, Stormwater runoff for selected watersheds in the Edwards aquifer recharge zone, Bexar County, Texas, 1996-98: U.S. Geological Survey Fact Sheet FS-172-98, 6 p.

Raines, T.H., 1996, Simulation of storm peaks and storm volumes for selected subbasins in the West Fork Trinity River Basin, Texas, water years 1993-94: U.S. Geological Survey Water-Resources Investigations Report 96-4110, 41 p.

Texas State Historical Association, 2002, The handbook of Texas online-Bexar County: Accessed January 6, 2003, at URL

http://www.tsha.utexas.edu/handbook/online/ articles/view/BB/hcb7.html

U.S. Census Bureau, 2002, State and county quickfactsBexar County, Texas: Accessed January 6, 2003, at URL http:/quickfacts.census.gov/qfd/states/48/48029.html

U.S. Department of Agriculture, Soil Conservation Service, 1966, Soil survey of Bexar County, Texas: 126 p., 88 sheets.

U.S. Environmental Protection Agency, 2002, National Pollutant Discharge Elimination System (NPDES): Accessed January 6, 2003, at URL http://cfpub.epa.gov/npdes/index.cfm 
